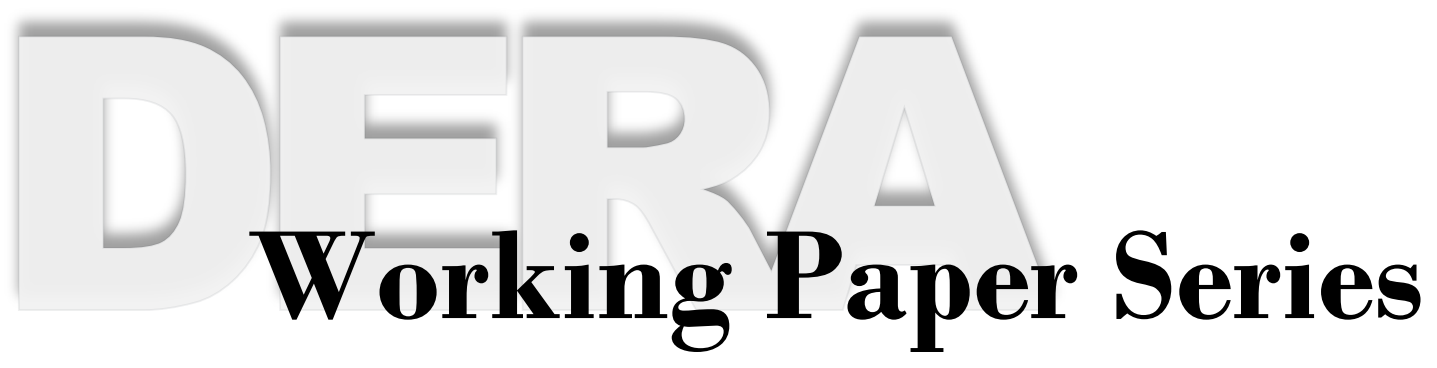

\title{
Appointments of Academic Directors
}

\author{
Joshua T. White
}

Tracie Woidtke

\author{
Harold A. Black
}

\section{Robert L. Schweitzer}

\section{DERA Working Paper 2013-02}

NOTE: Staff working papers in the DERA Working Paper Series are preliminary materials circulated to stimulate discussion and critical comment. References in publications to the DERA Working Paper Series (other than acknowledgement) should be cleared with the author(s) in light of the tentative character of these papers. The Securities and Exchange Commission, as a matter of policy, disclaims responsibility for any private publication or statement by any of its employees. The views expressed herein are those of the author and do not necessarily reflect the views of the Commission or of the author's colleagues on the staff of the Commission. 


\title{
Appointments of Academic Directors
}

\author{
Joshua T. White ${ }^{\text {a, * }}$ \\ U.S. Securities and Exchange Commission \\ whitejo@sec.gov \\ Tracie Woidtke ${ }^{b}$ \\ University of Tennessee \\ twoidtke@utk.edu \\ Harold A. Black ${ }^{b}$ \\ University of Tennessee \\ hblack@utk.edu \\ Robert L. Schweitzer ${ }^{c}$ \\ University of Delaware \\ schweitr@lerner.udel.edu
}

July 11, 2013

*Corresponding Author

${ }^{a}$ Division of Economic and Risk Analysis, U.S. Securities and Exchange Commission, $100 \mathrm{~F}$ Street NE, Washington, DC 20549. Tel.: +1- 202-551-6356; Fax: +1-202-772-9290.

${ }^{b}$ Department of Finance, College of Business Administration, University of Tennessee, 427 Stokely Management Center, Knoxville, TN 37996.

${ }^{\mathrm{c}}$ Department of Finance, Lerner College of Business \& Economics, University of Delaware, 303 Alfred Lerner Hall, Newark, DE 19716. 


\begin{abstract}
We examine the outside director selection process using unique data on appointments of academic directors. Overall, we find academic directors tend to be appointed by small- and midcap firms expanding their boards. However, we find important differences in both the factors influencing academic appointments and the market's reaction when allowing for heterogeneity. Academics in science, medicine and engineering appear to be appointed for their expertise, and the market reacts favorably. Academic administrators appear to be appointed for their networks, and the market reacts favorably when the administrator is affiliated with a business school but negatively when the administrator is not within close geographic proximity. Business and law professors appear to be appointed for general expertise and prestige, but we find little evidence of any significant market reaction.
\end{abstract}

Keywords: Corporate boards; Director selection; Academic directors; Director characteristics; Heterogeneity

JEL classification: G3, G30, G34 


\section{Introduction}

A substantial literature exists detailing the potential monitoring and advising benefits of outside directors. However, empirical challenges arise in separating the effects of outside directors from the endogenous director selection process (Adams et al., 2010). These challenges are exacerbated by heterogeneity among outside directors (Anderson et al., 2011). Thus, a better understanding of the outside director selection process and heterogeneities involved is critical to understanding the role of the board. Yet, how firms identify outside directors has received less attention in academic literature. The purpose of this paper is to contribute to filling this void.

To provide a detailed analysis of outside director appointments and the importance of heterogeneity, we focus our analysis on appointments of academic directors. This focus offers many advantages. First, concentrating on academics enables us to collect detailed data for a comprehensive sample of outside director appointments. Importantly, academic credentials provide clearly defined measures of heterogeneity to help us understand firm preferences when selecting outside directors. In addition to providing rich heterogeneity, academics also supply a significant source of outside directors for public boards. Over 33\% of S\&P 1500 firms have academic directors serving on their boards during 1998-2006 (Francis et al., 2011). Furthermore, we are interested in whether academics may help solve the dilemma faced by firms seeking outside directors who possess expertise and availability, but have fewer conflicts of interests.

Even though academics are potentially unique in their capacity for knowledge, availability and independence, they have received limited attention in the literature. The few studies that include some analysis of academic directors tend to treat academics as a homogeneous group and find few differences between academics and other outside directors (e.g., Rosenstein and Wyatt, 1990; Fich, 2005; Duchin et al., 2010; Agrawal and Chen, 2011). 
We postulate that the lack of significance in the literature may be due to the assumption of homogeneity among academics, which ignores the particular attributes that attract firms to academics as directors. In a recent working paper, Francis et al. (2011) allow for some heterogeneity among academics and find differences when examining the relation between firm performance and the presence of an academic director in a cross-sectional analysis. However, it is difficult to disentangle their results from the director selection process. Moreover, restricting their analysis to academic directors identified in the RiskMetrics database excludes many small firms, potentially limiting the generality of their study.

We investigate why firms appoint academics by asking two related research questions:

(1) What are the factors that influence the appointment of an academic director?

(2) Do market participants view academic director appointments differently based on firm and director heterogeneities?

To answer these questions, we analyze a unique, hand-collected dataset of academic board appointments between January 1, 1995, and December 31, 2007. Specifically, we examine firm, board, director, and appointment characteristics for 550 academic director appointmentsonly 284 of which are identifiable in RiskMetrics. We find academic directors tend to be appointed prior to being approved by shareholders at an annual meeting by small- and mid-cap firms. Sixty-five percent of academic appointments increase board size, and $45 \%$ include simultaneous appointments to a key committee. Thus, growing companies appear to view academics as a viable source of directors when expanding their boards.

We agree with Adams et al. (2010) that it is difficult to understand the role of boards without knowing how different firm constraints or characteristics affect the director selection process. Boone et al. (2007) and Coles et al. (2008) argue that board characteristics should vary 
with firm characteristics associated with different advising and monitoring needs. Anderson et al. (2011) find director heterogeneities may be sources of value for corporate boards. We therefore classify academic directors into three groups according to differences in training and experience to better understand why firms appoint academic directors, allowing for heterogeneity. In particular, we classify academic directors as: Administrative - academics with administrative leadership positions, e.g., presidents, chancellors, and deans; Business - professors with general business expertise, e.g., professors in business and law schools; and Specialized - professors with specialized expertise, e.g., professors in medicine, science, and engineering.

When treated as a homogeneous group, only two factors are significantly related to the likelihood of appointing an academic director compared to a sample of firms matched on industry and size: the percentage of directors appointed during the current CEO's tenure and the presence of another academic director on the board. Both are positively related to the likelihood of appointing an academic director. Conversely, when allowing for director heterogeneity, we find important differences in the factors influencing academic director appointments. Consistent with a firm desiring attributes specific to its needs, we find these factors vary with the type of academic director being appointed. Firms under greater scrutiny (i.e., separate Chairman and CEO, New York Stock Exchange (NYSE) listing, and greater institutional ownership) are more likely to appoint an Administrative academic from a university close in geographic proximity, increasing the likelihood of the academic being from a non-Top 25 University. Lesser-known firms (i.e., firms with shorter trading histories and smaller boards) with general business expertise needs (i.e., lower research and development [R\&D] and greater selling, general, and administrative [SG\&A] expenses) are more likely to appoint Business academic directors from prestigious business or law schools (i.e., Top 25 University, distant proximity). High growth, 
established firms (i.e., high sales growth and Tobin's Q, mid- and large-cap, and lower firm risk) with high information costs (i.e., Nasdaq listing, greater cash and R\&D, and specialized industry concentration) are more likely to appoint Specialized academic directors that are recognized experts in their field (i.e., Top 25 University, proximity insignificant).

Next, we examine whether market participants view academic director appointments differently based on firm and appointment characteristics. Like many previous studies, we find no significant market reaction to the appointment of academic directors when treated as a homogenous group. But, when allowing for heterogeneity in firm, director, and appointment characteristics, we find significant differences in how investors react to appointments of academic directors. Specialized appointments are met with a significant, positive market reaction on average. The reaction is significantly greater for firms that are smaller, spend more on R\&D and are expanding their board. The reaction is also significantly greater when the Specialized academic is at a school located farther away from the firm. Administrative appointments are met with an insignificant market reaction on average. However, the reaction is positive when the administrator is associated with a business school (e.g., dean) or is expanding the board. Conversely, the reaction is negative when an administrator replaces another director or is affiliated with an institution with distant proximity to the firm. Business appointments are met with an insignificant market reaction on average. However, the reaction is greater for smaller and lower risk firms and those spending more on advertising and less on SG\&A but lower when the Business academic is connected with the CEO's alma mater.

Our results show that recognizing director heterogeneity is important and that firms have different preferences for outside directors. Specialized directors are appointed primarily because of their expertise and for matters related to R\&D spending and are viewed as adding value to the 
firm. Administrative academics appear to be appointed for their networks (i.e., tend to have stronger geographic connections and sit on multiple boards) and are not viewed as adding value when net benefits are less evident (e.g., distant proximity, non-business, replacement of nonacademic). Business academics appear to be appointed for reasons related to school prestige but are not viewed as adding value.

The remainder of this paper is organized as follows. Section 2 discusses motives firms may have for appointing academic directors. Section 3 describes the sample. Section 4 provides comparative statistics, and Section 5 presents empirical results. Section 6 concludes.

\section{Motives for Academic Director Appointments}

Academics are potentially unique in their capacity to possess many qualities that firms desire in directors. We discuss five reasons a firm may appoint academic directors based on these qualities: monitoring, expertise, social connections, networks, and reputation. First, academics may be appointed because they are perceived to have the intellectual capacity to process information and are independent. Benefits of addressing agency problems through monitoring by outside directors are discussed extensively in the literature (e.g., Fama and Jensen, 1983; Weisbach, 1988; Brickley et al., 1994). Monitoring effectiveness increases with the ability to process information (Lehn et al., 2009), fewer conflicts of interest (Brickley et al., 1994), and greater access to non-public information (Ravina and Sapienza, 2010). Firms desiring greater participation at board meetings and service on key committees may appoint academic directors. Flexibility in academics' schedules could provide greater availability to attend meetings and serve on key committees, which would increase oversight of management and board selection (Vafeas, 1999; Adams, 2003). Academics may also be a source of more retired and female 
directors, which are both associated with greater attendance (Adams and Ferreira, 2008, 2009). Finally, firms may wish to appoint academics from geographically close universities to lower the cost of gathering information (Alam et al., 2013).

Second, director expertise impacts the counsel and advice directors provide to management, and expertise needs vary according to firm characteristics (Audretsch and Lehmann, 2006; Boone et al., 2007; Coles et al., 2008; Anderson et al., 2011). For example, Ariad Pharmaceuticals cites expertise in the clinical development of biotechnology products when appointing biochemistry professor Burton Sobel to its board. ${ }^{1}$ In a more general business setting, academics from business or law schools may be better suited to meet the advising needs of a firm than non-business academics. For instance, Synnex Corporation notes finance professor James Van Horne's “extensive background in corporate finance and budgeting decisions" as a "valuable source of Board guidance" in announcing his appointment. ${ }^{2}$ These attributes in academics may be particularly important to smaller firms, since they are least likely to successfully attract executive directors (Trautman, 2012) ${ }^{3}$ and also incur greater relative costs for complying with the Sarbanes-Oxley Act (SOX) and related board reforms (Linck et al., 2009). For example, small-cap firm Ryder System notes strong governance expertise when jointly appointing accounting professor Abbie Smith to its board and audit committee in $2003 .{ }^{4}$

Third, firms may appoint academic directors because of social connections. For example, Health Management Associates (HMA) appointed Randolph Westerfield, a dean at the CEO's

\footnotetext{
1 "Ariad appoints former Merck, Medimmune and Bristol-Myers Squibb senior executives and leading medical researcher to its Board of Directors" (Business Wire, June 19, 2002).

2 "Synnex Corporation announces the appointment of two new board members" (PRNewswire, September 29, 2005).

${ }^{3}$ Trautman (2012) cites firms responding to Spencer Stuart's 2010 Board Index survey sought to fill 48\% of board seats with active executives but only filled $26 \%$ of vacant seats with executives. Academics with business or specific industry knowledge may meet the advising needs of firms unable to attract executives to sit on their board.

4 “Abbie J. Smith, University of Chicago Professor of Accounting, Elected to Ryder System, Inc. Board of Directors" (PRNewswire, July 31, 2003).
} 
alma mater, the University of Southern California (USC), to its board in $2000 .{ }^{5}$ Appointing academics from the same degree school as the CEO or another director may reflect a preference for transacting with individuals of a known reputation (Gulati and Gargiulo, 1999). Social ties between the CEO and outside directors may also enhance trust and facilitate board involvement (Westphal, 1999). Conversely, CEOs may appoint outside directors with social ties, including a common alma mater, to reduce board dissent (e.g., Shivdasani and Yermack, 1999; Hwang and Kim, 2009). For example, Westerfield may be less likely to disagree with CEO and Chairman of HMA, William Schoen, after he becomes a significant donor and trustee at USC. ${ }^{6}$

Fourth, firms may appoint academic directors to gain access to networks. Academics within a firm's community may provide regional networking opportunities. These connections may assist in facilitating access to external resources such as loans (e.g., Guner et al., 2008), social networks (e.g., Lynall et al., 2003), and suppliers of other critical resources (Audretsch and Stephen, 1996). Firms may also value board members, such as academics in leadership positions at local universities, because of connections to state or local politicians (Goldman et al., 2009). When Frontier Airlines appointed Hank Brown - president of the University of Northern Colorado and former Colorado congressmen - to its board, their Chairman cited Brown's history as a leader of "some of Colorado's most respected institutions."”

Finally, a firm may appoint certain outside directors to enhance its reputation (Hambrick and D’Aveni, 1992; Daily and Schwenk, 1996). Academic directors from prestigious universities may be viewed as improving the reputational capital of the firm (Mattis, 2000; Singh et al., 2008) or as a signal of firm quality (Audretsch and Stephan, 1996). For example, in the wake of

\footnotetext{
5 "Health Mangement Associates, Inc. appoints Randolph W. Westerfield, Ph.D. to Board of Directors" (PRNewswire, May 16, 2000).

6 "Hospital Network Chairman appointed to USC Board of Trustees" (USC News Release, January 31, 2006); "USC receives \$10-million donation for military veteran scholarships" (Los Angeles Times, March 27, 2012).

7 "Hank Brown joins Frontier Airlines Board of Directors" (Business Wire, May 30, 2003).
} 
the Enron scandal, Kenneth Lay resigned his directorship at Eli Lilly. Martin Feldstein, professor of economics at Harvard University, replaced Lay as a director nine days later. ${ }^{8}$ Appointing an academic from a prestigious institution could be viewed as a step towards restoring the integrity and credibility of Eli Lilly's board. A firm may also signal its quality by attracting a leading expert (i.e., an academic from a prestigious university) to serve on its board.

\section{Sample Selection and Classification}

\subsection{Sample Selection}

The sample includes new appointments of academic directors from January 1, 1995, to December 31, 2007. Extant research shows factors influencing the appointment of academic directors vary by firm size and age (e.g., Boone et al., 2007). We hand collect academic director appointment data to ensure our sample includes appointments to small company boards for a comprehensive analysis. First, we search for academic directors by examining all proxy statements in the SEC's EDGAR database from 1995 to 2007 for the firms listed in the Fortune 1000 during 2007. When academic directors are identified, we also record board appointments of those directors listed in the proxy for firms outside of the Fortune 1000. Finally, we perform a Lexis-Nexis keyword search of press releases to identify other academic director appointments. ${ }^{9}$

Many studies rely on the RiskMetrics (formerly IRRC) database to identify director occupation information. However, we believe our sample construction is more appropriate for our research question for three reasons. First, we capture academic status at appointment. RiskMetrics lists employment category as "academic" even for directors who take a position at a

\footnotetext{
8 “Enron Exec Lay Leaves Lilly Board” (Associated Press, December 19, 2001).

${ }^{9}$ Specifically, we perform text searches for variants of (academ!, chanc!, pres!, universit!, provost, dean, prof!, lectur!, colleg!, inst!, school!, dr!, doctor!) within the same paragraph of (board, director!, appoint!, elect!, public!, join!, nominat!, firm!, meetin!, shareholde!, annual).
} 
university or college after being appointed to a board. ${ }^{10}$ Second, RiskMetrics' occupation data are missing for many director observations. ${ }^{11}$ We identify 93 academic appointments by firms covered in RiskMetrics whose occupation is not classified as "academic." Third, we identify 173 academic appointments not covered in RiskMetrics. ${ }^{12}$ Combined, these directors represent approximately half of our sample. Given the importance of certain director qualities likely varies with firm age and size, including appointments to firms not included in RiskMetrics allows us to conduct a broader analysis of the reasons different firms appoint academic directors.

Our search methodology identifies 919 appointments of directors with academic institution affiliation by publicly traded U.S. firms. We exclude 146 appointments by firms prior to initial public offerings or following mergers and acquisitions, spin-offs, and bankruptcies. We exclude 116 appointments by firms with missing financial and stock return data from Compustat and CRSP. Finally, we exclude 107 appointments by financial firms (SIC codes 6000-6999) due to differences in governance structures (Adams and Mehran, 2003). Our final sample size is 550 appointments for 372 directors at 426 firms.

\subsection{Academic Director Classification}

We classify academic directors into three groups according to differences in training and experience as follows: ${ }^{13}$

(1) Administrative - presidents, chancellors, deans, provosts, vice presidents, chief operating

\footnotetext{
${ }^{10}$ For example, General Robert H. Foglesong retired from the U.S. Air Force on February 1, 2006, following 33 years of military service. He joined the board of Massey Energy on February 21, 2006, and was elected president of Mississippi State University on April 16, 2006. RiskMetrics lists Gen. Foglesong as an academic, but we do not consider this to be an academic director appointment since the board appointment preceded the academic status.

${ }^{11}$ RiskMetrics data on director occupation are not complete and are not available prior to 1997.

${ }^{12}$ Thirty-five 1995 appointments predate coverage by RiskMetrics, and 138 appointments during 1996-2007 are not covered by RiskMetrics.

${ }^{13}$ Sixteen academics do not fall into these three groups. This includes professors of history, political science, government, human relations, public policy, and others. Since these are so few and tend to be most similar to Administrative, we include these with Administrative. Our results are robust to treating them as a separate category.
} 
officers, and directors of special centers. Administrative academics hold key leadership positions at their institution and have experience working with different groups, including external constituents. For example, Wendy's International cites "experience in leading large, complex organizations" when appointing William Kirwan, president of The Ohio State University, to its board. ${ }^{14}$ The visibility of administrative positions and relational experience may yield beneficial social and political networks and access to additional resources or prestige for appointing firms. On the other hand, Administrative academics are typically not active in research and are often trained in non-technical disciplines. They are less likely to provide the same level of technical or business advice as professors who are actively engaged in research in business or industry-specific fields. For example, Robert K. Jaedicke, Dean of the Graduate School of Business at Stanford University, and professor of accounting, chaired the audit committee at Enron beginning in 1985. As shareholders became aware of financial statement fraud at Enron in early 2002, some wondered how an expert in accounting from a prestigious institution failed to spot cost discrepancies. The New York Times opined that Dean Jaedicke may have missed Enron's fraudulent transactions since he had not been active in research for over thirty years. ${ }^{15}$

(2) Business - professors in business and law schools. Business academics are nonadministrative professors with general business expertise. These academics may be more likely to possess the knowledge necessary to monitor and provide advice with respect to legal compliance or best business practices. This knowledge may be particularly valuable for firms unable to obtain counsel from costly consulting firms or experienced outside executives. For example, CKE Restaurants mentions law professor Janet Kerr's experience as a consultant

\footnotetext{
14 "Wendy's Appoints William Kirwan to Board of Directors" (PRNewswire, February 20, 2001).

15 "Professor Who Led Audit Panel Failed to Spot Smoke and Mirrors" (New York Times, February 7, 2002).
} 
and depth of experience in corporate and securities matters and SOX compliance when appointing her to its board. ${ }^{16}$

(3) Specialized - professors in medicine, chemistry, physics, biology, and engineering. Specialized academics are trained in highly technical disciplines that are unique to certain industries. These academics may be valued by firms seeking research knowledge spillovers or in firms where the transfer of knowledge is more costly (e.g., R\&D intensive firms). ${ }^{17}$ For example, genetics professor Michael S. Brown's research involving genes that regulate cholesterol likely advances Pfizer's research and development efforts. ${ }^{18}$

\subsection{Academic Director Distribution}

The distribution of academic director appointments by proxy year is displayed in Table 1 . Of particular note is when academic directors are generally appointed during the proxy season. Over $76 \%$ of academic director appointments are made prior to a firm's annual meeting, indicating most academics are appointed to the board prior to being presented to shareholders for a vote. Because annual meetings are generally scheduled during the middle of the calendar year, appointments during the first part of 1995 and the latter part of 2007 will only capture a portion of appointments for the 1995 and 2008 proxy seasons. For the remaining proxy years, two peaks appear in the distribution. The first peak occurs over the 1997 proxy season, and the second peak occurs over the 2002-2004 proxy seasons. The peak during 2002-2004 is primarily driven by

\footnotetext{
16 “CKE Restaurants, Inc. Announces Appointment of Janet E. Kerr to Board of Directors; Law Professor Brings Corporate Law and Securities Experience to CKE Board” (PRNewswire, April 5, 2004).

17 In untabulated results, we examine the industry distribution of academic directors using the 48 industries identified by Fama and French (1997). Overall, academic director appointments are most common in the Business Services industry (15\%). Industry distribution by category shows Specialized directors are frequently appointed to Pharmaceutical Product firms (29\%), while Business academics see frequent appointments in the Retail industry $(17 \%)$. We find little evidence of industry clustering for Administrative academic directors. Overall, the differences in industry distribution by academic director type support our categorization based on expertise.

${ }^{18}$ See "Dr. Michael S. Brown Elected to Pfizer Board of Directors" (PRNewswire, June 4, 1996). According to Pfizer's 1997 10-K, they launch Lipitor, a cholesterol-lowering product, the year following Brown's appointment.
} 
appointments of Administrative and Business directors and coincides with changes in independent director requirements by the NYSE and the passage of SOX. ${ }^{19}$ The frequency of academic director appointments falls after the 2005 proxy season.

\section{<Insert Table 1 >}

The most common type of academic appointment is Administrative, which represents $60 \%$ of all academic appointments in our sample. Business academics comprise $26 \%$ of the sample, followed by Specialized academics at 14\%. The yearly distribution of Administrative and Business director appointments largely matches the overall distribution. However, the percentage of Specialized director appointments does not exhibit a similar peak during the 20022004 period. The difference in distribution for Specialized appointments indicates they may be appointed to serve a different function than Administrative and Business academics.

\section{$<$ Insert Table $2>$}

Certain academic characteristics, such as prestige and social network, may be associated with the academic's institution. Table 2 presents institution affiliation for our sample. Approximately 59\% (58\%) of appointments (academics) are affiliated with 26 institutions, while the remaining $41 \%(42 \%)$ are distributed across 128 institutions. The largest contributor is Harvard University with a total of 78 appointments for 48 distinct academics, or $14.2 \%$ (12.9\%) of appointments (academics). It is followed by Stanford University with $4.4 \%$ (5.4\%) of appointments (academics) and Massachusetts Institute of Technology with $3.8 \%$ (3.8\%) of appointments (academics). No other institution has greater than $3.0 \%$ of academic appointments.

\footnotetext{
${ }^{19}$ NYSE Rule 303.01 requires the audit committee of a listed company have at least one director with accounting or financial expertise (see http://www.nyse.com/pdfs/corp_recommendations_nyse.pdf). Under Section 407 of the Sarbanes-Oxley Act, a firm must appoint an audit committee financial expert or explain why one is not appointed (see http://www.sec.gov/rules/final/33-8177.htm).
} 


\section{Comparative Statistics of Academic Appointments}

To examine why firms appoint academic directors, we begin by comparing firm and board characteristics. The Appendix provides a description of each variable. To determine if patterns are identifiable across different subgroups of academic directors, we compare firm and board characteristics to a matched sample of similar sized firms operating in the same industry and across academic director type. The matched sample consists of firms without an academic director appointment during the prior year for which data are available from CRSP, Compustat, and RiskMetrics. We first select a firm with the same 3-digit SIC code and a book value of total assets within $20 \%$. If no firm meets these criteria, the criteria are relaxed to 2-digit SIC code and size within $30 \%$ of total assets.

\subsection{Appointing Firm and Board Characteristics}

In order to proxy for firms' needs for academic director functions, we first examine the characteristics of firms appointing an academic director in Panel A of Table 3. We examine appointing board characteristics in Panel B. In each panel, we compare the results for all academic directors to the matched firm in Column (1). For ease of presentation, we do not present the mean values for the matched firms. Instead, we denote in Column (1) when the sample means are significantly greater than $(+)$ or less than $(-)$ match firm means at the $10 \%$ significance level or better. In order to understand the implications of director heterogeneity, we compare the appointing firm and board characteristics across academic director category in Columns (2) to (4). Institutional Ownership data are obtained from the Thomson Reuters (13f) Holdings Database, and available G-Index data are obtained from the RiskMetrics governance database. All other data are obtained from CRSP and Compustat. 


\section{$<$ Insert Table 3>}

Appointing and match firms are similar along several dimensions. Approximately $38 \%$ of appointing firms are classified as small-cap firms, 35\% as mid-cap firms, and 27\% as large-cap firms. Although firms are similar in average size according to assets and sales, firms appointing an academic director have a significantly larger mean market capitalization than match firms. ${ }^{20}$ Appointing and match firms have been publicly traded for around 22 years, have institutional ownership close to $60 \%$, are primarily listed on the NYSE, use approximately $20 \%$ long-term debt financing, have a G-Index of 9, and have similar risk. However, there are a few significant differences. Firms appointing academic directors tend to hold more cash and spend more on advertising, experience greater sales growth but have lower free cash flow, and experience greater raw stock returns but have lower market-adjusted returns.

The next three columns present the sample means for each subgroup. Significance levels indicate differences between the subgroup in the column and the rest of the academic appointment sample. Consistent with the view that firms with different characteristics have different functional needs for directors, we find differences across firms according to the type of academic appointed. Firms appointing Specialized academics tend to be most different. They have the greatest growth opportunities, measured by both Tobin's Q (2.8) and prior sales growth (58\%), the lowest operating performance $(3.5 \%)$ and free cash flow $(-1.2 \%)$, and the greatest spending on R\&D (11\%). These firms are also the least likely to be listed on the NYSE (48\%) and have the lowest institutional ownership (53\%). On the other hand, firms appointing Administrative academics tend to have the longest listing history (23.6 years), have the greatest

\footnotetext{
${ }^{20}$ There is no statistical difference in the median values of market capitalization between the sample and matched firms (untabulated). The difference in means is driven by academic director appointments to some of the largest U.S. firms by market capitalization, such as General Electric, Microsoft Corporation and ExxonMobil. To ensure these firms are not driving our multivariate results, we re-run all of our tests using alternative measures of firm size. The results are similar.
} 
institutional ownership (61\%), use the most short-term borrowing (4.4\%), and be most frequently listed on the NYSE (74\%) relative to other appointing firms. Finally, firms appointing Business academics have the shortest listing history (18.3 years), are most likely to be small cap (44\%), use the least amount of short-term borrowing (3.0\%), spend the least on R\&D (3.0\%), but spend the most on advertising (2.6\%) and SG\&A expenses (30\%).

Panel B presents descriptive statistics for appointing boards. Independence is taken from RiskMetrics and proxy statements. Consistent with similarities in firm characteristics, appointing firms' mean board size and independence are similar to that of match firms. Appointing boards are comprised of 9.3 directors with $63 \%$ independence, on average. Also similar to match firms, $59 \%$ of appointing firms have a classified board, $31 \%$ have the CEO serving on the nominating committee, and $70 \%$ have the CEO serving as Chairman of the Board. In contrast to match firms, appointing firms are significantly more likely to have an academic director currently serving on the board $(48 \%),{ }^{21}$ and a greater proportion of current directors on appointing boards are appointed during the current CEO's tenure (55\%). However, shorter CEO tenure by appointing firms suggests the greater proportion of director appointments is due to greater director turnover and/or expansion rather than an entrenched board resulting from long CEO tenure (untabulated). Appointing boards also have a higher proportion of employee directors.

When comparing board characteristics across firms categorized by academic type, we find many similarities. However, two notable differences are that boards appointing Business academics tend to be smaller than other appointing boards with fewer than 9 directors, and boards appointing Specialized academics are much more likely to have other academics currently serving on the board. Their boards have an average of 1.2 academic directors with $68 \%$ having at

\footnotetext{
${ }^{21}$ We repeat the analysis excluding academic director appointments not identified by the Lexis-Nexis search to ensure appointments identified solely through proxy statements do not drive the finding of an academic director already serving. The results are robust.
} 
least one academic director serving on their board prior to the appointment.

\subsection{Academic Director and Appointment Characteristics}

Table 4 presents descriptive statistics on academic director and appointment characteristics. Information regarding an academic director's university position, age, gender, other directorships, and committee membership at appointment is hand collected from proxy statements, press releases, and curricula vitae. Biographical information on academic directors and CEOs is augmented with data from Dun \& Bradstreet's Reference Book of Corporate Managements. Academic institution data are obtained from university websites. We label an institution a Top 25 University based on rankings in the 2008 U.S. News \& World Report.

\section{<Insert Table 4>}

Panel A provides director characteristics for the first appointment and full sample. Overall, the characteristics are similar. The average age of newly appointed academic directors is 56 years. This is less than the average age of directors appointed to the S\&P 500 in 2000 and 2010 (60 and 62, respectively; Trautman, 2012). Business academics are the youngest on average at 54 years. Female academic directors constitute $22 \%$ of our sample, which is more than double the representation of women directors on S\&P 1500 boards over 1996 to 2003 (Adams and Ferreira, 2007) and greater than the proportion of females appointed to S\&P 500 boards in 2000 and 2010 (12\% and 16\%, respectively; Trautman, 2012). The higher proportion of female academic appointments, especially Administrative (24\%) and Business (22\%) directors, may reflect a larger pool of qualified female academics versus the pool of female executives. The 
proportion of female appointments is the lowest in Specialized appointments (11\%), which is similar to the proportion of female executives within these specialized industries. ${ }^{22}$

Over $97 \%$ of academics are classified as independent. Nearly $88 \%$ are affiliated with an academic institution at the time of appointment, while $9 \%$ are retired. Private universities (67\%) supply more academic directors than public universities in all academic categories. While Business (74\%) and Specialized (69\%) appointments tend to come from Top 25 Universities as well, Top 25 Universities are only associated with $44 \%$ of Administrative appointments. Surprisingly, although Harvard University supplies the largest number of academic directors, Ivy League universities have the lowest representation among our different measures of institutional quality or prestige. Only $24 \%$ of academic appointments are from Ivy League universities, and the representation ranges from $13 \%$ of Administrative appointments to $44 \%$ of Business appointments. Just fewer than $40 \%$ of academic appointments are from business schools, but the proportion varies greatly from $0 \%$ for Specialized to $28 \%$ for Administrative to $87 \%$ for Business. Academic directors average $1.3(0.8)$ other directorships across all appointments (at first appointment). Including the appointment, almost one-third (18\%) of the full (first appointment) sample holds three or more directorships and is considered a "busy" director (Fich and Shivdasani, 2006). Administrative academics are the busiest, with $34 \%$ being classified as busy; and Specialized academics are the most focused, with only $17 \%$ being classified as busy. One possibility is that Administrative academics are valued for their connections which increase with multiple directorships (Coles et al., 2012), while Specialized academics are valued for their technical expertise and advisory role, which may diminish with the time constraints of multiple directorships. Specialized expertise also may not transfer to as many firms because of its focused

\footnotetext{
${ }^{22}$ This result is consistent with Carrell et al. (2010), who find that gender gaps persist in graduate degrees in science, technology, engineering and math (STEM) professions, but have largely disappeared in business and law.
} 
nature and/or non-compete agreements. We examine the most frequently appointed academic directors more closely in Table 5.

Panel B of Table 4 presents various connections an academic director may have with the appointing firm. Social connections with the CEO are measured in two ways. The academic has a direct social connection if the CEO's degree school matches the academic director's current school. An indirect social connection exists if the CEO's degree school matches the academic's degree or current school, including any undergraduate or graduate degrees but not honorary degrees. We also measure direct social connections with existing academics on the board or those who exit the board prior to but in the same fiscal year of the new academic appointment. Lastly, distance is used to measure regional connections and is calculated as the surface distance (in miles) between the address for the academic institution and firm headquarters.

Academic directors and CEOs share educational affiliation in $16 \%$ of the sample, while the CEO's degree school employs $11 \%$ of academic directors at appointment. The educational connection is strongest for Business appointments with $22 \%$ sharing some educational connection with the CEO. Educational ties with an existing academic director are much less pronounced than CEO connections for Administrative and Business appointments but are similar in magnitude for Specialized appointments, though still modest at $11 \%$. Although educational connections are weakest for Administrative academics, their geographic connections appear to be the strongest as Administrative academics are approximately 300 miles closer to appointing firms than Business or Specialized academics. Stronger geographic connections combined with the largest proportion of busy directors suggest Administrative academics are more likely to be appointed for their networks than for greater availability or less costly monitoring. 
Panel C presents appointing board changes associated with an academic appointment. Appointing boards tend to expand with academic appointments (65\%) resulting in boards that are larger than match sample boards by 0.7 to 1.0 directors, on average, depending on academic type. This result is consistent with Linck et al. (2008) who find boards tend to add independent directors through expansion rather than replacement. Only 38\% of academic appointments replace a departing director, and less than $8 \%$ replace a departing academic. Thus, over $90 \%$ of academic appointments increase representation by academics on the appointing board. Moreover, $45 \%$ of academic appointments include a key committee appointment at the time of appointment. Around $30 \%$ of Administrative and Business academics are appointed to the audit committee. In contrast, only $13 \%$ of Specialized academics join the audit committee at appointment. ${ }^{23}$

Panel D presents the average total compensation for the subset of academic directors that are appointed during 2004 to 2007 and have data available for at least one year during the 2006 to 2009. fiscal period. ${ }^{24}$ Compensation data are obtained from Execucomp and proxy statements. On average, total annual academic director compensation ranges from a low of \$171,000 in 2006 to a high of $\$ 189,000$ in 2008 per board appointment. Across categories, Administrative academics receive the highest board compensation, ranging from an annual average of $\$ 363,000$ to $\$ 449,000$ per board appointment. Specialized academics show the greatest fluctuation in average annual compensation, falling from $\$ 255,000$ in 2007 to $\$ 164,000$ in 2008 . This could be explained by the greater proportion of total compensation in the form of stock and option awards for Specialized academics during this period (untabulated).

\section{$<$ Insert Table 5>}

\footnotetext{
${ }^{23}$ With the exception of the decrease in the proportion of academics classified as "busy," the results in Table 4 are similar when considering only the earliest appointment for each academic director.

${ }^{24}$ Analysis is restricted to this period because tabulation of individual director compensation is limited for proxy statements filed prior to December 15, 2006 (see http://www.sec.gov/rules/final/2006/33-8732a.pdf).
} 
As Tables 2 and 4 indicate, many academic directors have multiple appointments during the sample period. We tabulate a list of the ten most frequently appointed academics in Table 5. Consistent with Administrative academics being in greatest demand, i.e., the busiest and most highly compensated directors, 7 of the 10 most frequently appointed academics are Administrative. Shirley Jackson, president of Rensselaer Polytechnic Institute, is appointed to 9 boards and serves on a maximum of 8 other boards across her appointments. Eight of the 10 most frequently appointed academics are from non-Ivy league schools. Only one Specialized and two Business academics are included, while three of the most frequently appointed are female Administrative directors.

Taken together, the comparative statistics are consistent with differences in roles across academic classifications. The director characteristics and connections suggest that regional prestige and networks, board experience and lower information costs are potentially important factors for Administrative appointments; national reputation, board experience and educational connections are potentially important factors for Business appointments; and years of specialized research and national reputation are potentially important factors for Specialized appointments.

\section{Empirical Results}

In this section we investigate our central research questions, allowing for heterogeneity: (1) which factors are associated with the likelihood of academic director appointments, and (2) how does the market perceive academic director appointments. 


\subsection{Analysis of Academic Director Appointments}

We analyze the likelihood of appointing a certain type of academic director based on board and firm characteristics. Columns (1) to (3) in Table 6 report the results of a multinomial logit model estimating the relation between firm and board characteristics and the likelihood of appointing a certain type of academic compared to not appointing an academic of any type. The dependent variable is equal to 0 when no academic is appointed, 1 when an Administrative academic is appointed, 2 when a Business academic is appointed, and 3 when a Specialized academic is appointed. Columns (4) to (6) present the results of three separate logit models of the choice to appoint a certain type of academic conditional on appointing an academic and including academic-specific characteristics as independent variables. Thus, the logit models in Columns (4) to (6) each estimate the relation between firm, board, and academic characteristics and the likelihood of appointing a certain type of academic compared to appointing another type of academic. All models use robust standard errors clustered at the firm level. We also include a SOX indicator variable that equals 1 if the appointment is after 2002.

\section{$<$ Insert Table 6>}

The results indicate that significant heterogeneity exists. Only two factors are significantly related to the likelihood of appointing an academic director, regardless of type. The significant, positive coefficients for Existing Academic on Board and Captured Directors in Columns (1) through (3) indicate the likelihood of appointing an academic director of any type increases with the percentage of directors appointed during the current CEO's tenure and the presence of an academic director already sitting on the board. However, consistent with firms desiring attributes specific to their needs, other factors influencing the likelihood of appointing an academic director vary with the type of academic director being appointed. Firms listed on the 
NYSE, having a separate Chairman and CEO, and spending more on advertising are more likely to appoint an Administrative academic than firms not appointing academic directors. Firms listed on the NYSE, having shorter public trading histories, and having greater advertising and SG\&A expenses but lower R\&D expenses are more likely to appoint Business academics. Neither the likelihood of appointing Administrative or Business academics increases after SOX when controlling for other factors. Finally, firms not classified as small cap and firms with more cash, lower firm risk, and lower institutional ownership are more likely to appoint Specialized academics than firms not appointing academic directors.

Among firms that appoint academic directors, we also see differences in factors influencing the type of academic appointed in Columns (4) to (6). The likelihood of an Administrative appointment is positively related to a separation of CEO and Chairman, listing on the NYSE, and institutional ownership and negatively related to academic institution prestige and distance to the appointing firm. The likelihood of a Business appointment decreases with board size and R\&D spending but increases with SG\&A spending, academic institution prestige, and distance from the appointing firm. Finally, the likelihood of a Specialized appointment decreases with listing on the NYSE, designation as a small-cap company, and institutional ownership but increases with the presence of an existing academic director and academic institution prestige. The likelihood of a Specialized rather than Administrative or Business appointment also decreases after SOX, indicating a proportional shift to these other types. ${ }^{25}$

\footnotetext{
${ }^{25}$ In untabulated results, we restrict our sample to observations where the director can be identified as "academic" using information in RiskMetrics. Only 52\% of our appointments are included and classified as academic in RiskMetrics. Many of the full-sample directors excluded from RiskMetrics are appointed by small-cap and Nasdaqlisted firms. The restricted sample analysis results in many differences. For example, distance is no longer significantly related to the likelihood of the academic appointment being Administrative, but becomes negatively related to the appointment being Specialized. Moreover, CAARs for Specialized appointments become significantly negative and less than those for other academic appointments. Overall, differences in results between the full and restricted samples are substantial and illustrate the importance of recognizing and addressing the restrictions of electronic databases for the validity and interpretation of empirical findings.
} 
The primary results are robust to using different definitions of CEO connection, distance, firm size, and performance. However, results vary with different definitions of prestige. While results are similar for Administrative and Business appointments, they become insignificant for Specialized appointments when Ivy League or Private is substituted for Top 25 University. We additionally run a linear probability estimation of Academic appointment type including fixed industry effects (untabulated). The results are similar overall, with some industry-related characteristics (e.g., R\&D) losing some significance as related industry effects load significantly.

\subsection{Market Reaction to Academic Director Appointments}

To better understand the different roles of academic directors, we investigate: (1) whether the market's perception of academic director appointments varies by classification and (2) what factors influence investor perception. We examine two-day $[-1,0]$ cumulative abnormal announcement returns (CAARs) using standard event study methodology. We estimate a market model using the CRSP equal-weighted index over the 255 days ending 46 days before the appointment announcement date. We define the announcement date (day 0) as the earlier of the announcement press release from a Lexis-Nexis search or the mailing date from the first proxy statement in which the academic's name appears. CAARs are presented in Table 7.

\section{<Insert Table 7>}

Panel A presents the mean and median CAARs for all appointments by category. Panels $\mathrm{B}$ and $\mathrm{C}$ present CAARs according to whether or not the academic is at a Business School. Panels D and E present CAARs according to whether the academic institution is in close (less than or equal to the median) or distant (above the median) proximity to the appointing firm. Panels $\mathrm{F}$ and $\mathrm{G}$ present CAARs according to whether the appointment expands the board or 
replaces a departing director. When pooling all appointments together, mean CAARs are significant and positive only for Specialized appointments $(0.96 \%) .{ }^{26}$ There is no significant market reaction to appointments of Administrative or Business academics. However, when appointments are separated according to whether an academic is at a Business School, within close proximity or is replacing a director, differences arise. There is a significant, positive reaction to Administrative appointments from Business Schools (mean: 0.62\%, median: 0.55\%) and those expanding the board (median: 0.23\%). Conversely, there is a significant, negative reaction to Administrative appointments from non-Business Schools (mean: -0.54\%), with distant proximity (mean: $-0.83 \%$ ) and replacing a departing director (mean: $-0.93 \%) .{ }^{27}$ Unlike Administrative appointments, the significant, positive reaction to Specialized appointments is for those from non-Business schools by definition and for those with distant proximity (mean: 2.41\%, median: $1.38 \%$ ). Taken together, the positive CAARs to distant Specialized appointments and the negative CAARs to distant Administrative appointments indicate any geographical boundaries placed on the contribution of academic directors is removed when the expertise is clear to market participants. ${ }^{28}$ Similar to Administrative appointments, the market reaction to Specialized appointments expanding the board is positive. There is no significant market reaction to Specialized appointments with close proximity or those replacing a director. None of the CAARs for Business appointments are significant. ${ }^{29}$

\footnotetext{
${ }^{26}$ When treated as a homogenous group, the CAARs for all academic director appointments are not significantly different from zero (untabulated). This is consistent with prior research (e.g., Fich, 2005).

${ }^{27}$ In untabulated results, we find that institutional ownership increases after Administrative appointments and leverage increases after Administrative appointments when administrators are within close proximity. Although exploratory in nature, these results suggest possible ways firms may benefit from Administrative connections.

${ }^{28}$ We find an increase in institutional ownership and the number of seasoned equity offerings following Specialized appointments (untabulated) suggesting possible benefits from such appointments may be related to increased investor interest. We also find $8 \%$ of these appointments are followed by value creating acquisitions within 2 years.

${ }^{29}$ Although we are naturally interested in whether CAARs are related to expertise in finance, we are unable to analyze this in a meaningful way because of small sample size. Only $2.5 \%$ of all academic appointments and $10 \%$ of Business academic appointments are finance professors.
} 
Given the differences in factors influencing academic appointments across categories and differences in the univariate results for the CAARs, we regress CAARs against firm, board, and academic characteristics to better understand the factors associated with the benefits and costs of academic director appointments by category. The results are presented in Table 8 .

\section{<Insert Table 8>}

CAARs for all academic appointments are presented in Column (1), and separately for Administrative, Business and Specialized appointments in Columns (2) to (4), respectively. The results for the full sample indicate that CAARs are positively related to board size, R\&D and advertising spending, prior operating performance, and academics at business schools but are negatively related to firm size and SG\&A spending. Moreover, CAARs for academic appointments are lower when a non-academic director is replaced as opposed to expanding the board but are greater when another academic director is being replaced.

The results in Columns (2) to (4) indicate the factors influencing the market's perception of the net benefits associated with appointments of academic directors vary with academic type. Announcement returns to Administrative appointments appear to be driving the different relation between the full sample CAARs and replacements of non-academic directors and replacements of academic directors. Unique to Administrative appointments, CAARs are greater when the Administrative director is closer to the firm. CAARs are also positively related to Administrative academics with business school affiliation (e.g., dean). Announcement returns to Business appointments appear to be driving the positive relation between full sample CAARs and advertising spending. For Business appointments, CAARs are not related to distance or R\&D spending, are negatively related to CEO connections and firm risk, and are positively related to advertising. CAARs for Specialized appointments are greater when a Specialized academic's 
university is private and greater when the university is farther away. CAARs are not significantly related to university prestige when measured by Top 25 University or Ivy League. Lastly, CAARs to Specialized appointments are not related to SG\&A spending. Thus, the results in this paper indicate the factors influencing academic director appointments vary according to academic categories, and the market values their appointments differently.

\section{Conclusion}

In this paper, we study the director selection process by examining appointments of academic directors. Focusing our analysis enables us to identify and collect detailed data for a comprehensive sample that provides rich heterogeneity across firm and director characteristics at the time of appointment. We posit that academics may be appointed for monitoring, expertise, social connections, networks, and reputation. We examine the factors that influence the appointment of an academic director and whether market participants view academic director appointments differently based on firm and director heterogeneities.

We find significant evidence of heterogeneity in director appointments of academics. Consistent with firms desiring attributes specific to their needs, factors influencing academic director appointments tend to vary with the type of academic director being appointed. Specialized academics appear to be appointed for their reputation and expertise. Their institutions' reputation is more important than close proximity, and their appointing firms tend to list on Nasdaq, have greater $\mathrm{R} \& \mathrm{D}$, and be concentrated in research-intensive industries. Administrative academics appear to be appointed for their networks. Their close proximity is more important than their institutions' prestige, and their appointing firms tend to list on NYSE and show no industry concentration. Business academics appear to be appointed for general 
expertise and prestige. Their institutions tend to be prestigious and farther away, and appointing firms tend to have smaller boards and lower R\&D but greater SG\&A. We also find heterogeneity in announcement returns to academic appointments. The market reacts favorably to Specialized appointments in general. However, the market only reacts favorably to Administrative appointments when the administrator is affiliated with a business school and when the administrator is appointed to a new board seat. The market reacts negatively when an administrator is not within close proximity and when an administrator replaces a director. We find little evidence of any significant reaction to Business appointments. Overall, our results suggest that different firms have different preferences for outside directors and the market perceives these differences. Thus, our study highlights the importance of recognizing heterogeneity in the director selection process. 


\section{Acknowledgments}

We thank Audra Boone, Joe Carcello, Ioannis Floros, Frank Glassner, Joan Heminway, Craig Lewis, Greg March, Mike McDonald, Sabur Mollah, Warren Neel, and seminar participants at the University of Tennessee Corporate Governance Center and 2012 FMA Annual Meeting for helpful comments. We thank Joel Savary for excellent research assistance. We also thank an anonymous referee for suggestions that improved this paper. The U.S. Securities and Exchange Commission, as a matter of policy, disclaims responsibility for any private publication or statement by any of its employees. The views expressed herein are those of the authors and do not necessarily reflect the views of the Commission or of the authors' colleagues on the staff of the Commission. 
Appendix

Variable Definitions

\section{Firm Variables}

Advertising Intensity $^{*}=($ advertising expenditures / total assets $)$

Cash-to-Assets ${ }^{*}=$ cash and short-term investments / total assets

Firm Age = number of years since the first trading date in CRSP

Firm Risk $^{* * *}=$ (standard deviation of daily returns - CRSP equal-weighted index return)

Free Cash Flow ${ }^{*}=$ (operating cash flow -cash dividends) / total assets

G-Index = Gompers et al. (2003) governance index for the year prior to appointment

Inside Ownership = percentage of outstanding shares held by insiders

Institutional Ownership ${ }^{*}=$ percentage of outstanding shares held by institutions

Large Cap ${ }^{* *}=1$ if the firm's market capitalization is greater than $\$ 5$ billion; otherwise 0

Long-Term Debt ${ }^{*}=$ (long-term debt / total assets)

Market Capitalization $^{* *}=$ market value of common equity

Mid Cap $^{* *}=1$ if the firm's market capitalization is between $\$ 1$ and $\$ 5$ million; otherwise 0

Number of Shareholders ${ }^{*}=$ number of common or ordinary shareholders

NYSE Listing $=1$ if the firm is listed on New York Stock Exchange; otherwise 0

Prior 1-Year Adjusted Return ${ }^{* * *}=$ (buy-and-hold return - CRSP equal-weighted index buy-and-hold return)

Prior 1-Year Return ${ }^{* * *}=$ buy-and-hold return

Prior Operating Performance $=$ (operating income / total assets)

Prior Sales Growth ${ }^{*}=$ percentage increase in sales from prior fiscal year

R\&D Intensity ${ }^{*}=$ (research and development expenditures / total assets)

Sales ${ }^{*}=$ (total revenue / total assets)

SG\&A Intensity ${ }^{*}=$ (selling, general and administrative expenditures / total assets)

Short-Term Debt ${ }^{*}=$ (short-term debt $/$ total assets $)$

Small Cap ${ }^{* *}=1$ if the firm's market capitalization is less than $\$ 1$ billion; otherwise 0

Tobin's $Q^{*}=$ [(total assets - shareholder's equity + market capitalization $) /$ total assets $]$

Total Assets ${ }^{*}=$ book value of assets

\section{Board Variables}

Board Size $=$ total number of directors

Captured Directors = percentage of independent directors hired after the appointing CEO

$\mathrm{CEO}$ is Chair $=1$ if the $\mathrm{CEO}$ is the Chairman of the Board; otherwise 0

CEO Nominating Committee $=1$ if the CEO is a member of the nominating committee or no similar committee exists; otherwise 0 
Classified Board $=1$ if the firm has a staggered director nomination process; otherwise 0

Employee Directors = percentage of employee directors

Existing Academic Directors = number of academic directors serving on the board

Existing Academic on Board $=1$ if the board has one or more academic directors; otherwise 0

Independent Directors = percentage of non-employee, non-related directors

\section{Director Variables}

Academia $=1$ if employed by a university at appointment; otherwise 0

Age $=$ academic director's age in years

Audit Committee $=1$ if the academic immediately joins audit committee; otherwise 0

Business School $=1$ if academic works in the business or commerce school; otherwise 0

Busy Director $=1$ if the academic holds three or more total directorships including the appointment; otherwise 0

CEO Direct (Indirect) $=1$ if CEO's alma mater is the academic's current school (or degree school); otherwise 0

Compensation Committee $=1$ if the academic immediately joins the compensation committee; otherwise 0

Corporate Governance Committee $=1$ if the academic immediately joins the corporate governance committee; otherwise 0

Directorships $=$ number of other board seats help at appointment.

Distance $=$ distance in miles between academic institution and corporate headquarters.

Existing Academic Connection $=1$ if the academic and another board member are employed by the same institution; otherwise 0

Expanding Board $=1$ if the academic appointment expands the board size; otherwise 0

Female $=1$ if the academic is a female; otherwise 0 .

Financial Expert $=1$ if the academic has an advanced degree or is a faculty member in accounting, or is a CPA; otherwise 0

Independent $=1$ if the academic meets the definition of an independent director; otherwise 0

Ivy League $=1$ if the academic is employed by Brown, Columbia, Cornell, Harvard, Princeton, Yale, Dartmouth or Penn; otherwise 0

Key Committee Appointment $=1$ if the academic joins the audit, nominating, governance, or compensation committee; otherwise 0

Nominating Committee $=1$ if the academic immediately joins the nominating committee; otherwise 0

Private University $=1$ if the academic is affiliated with a private institution; otherwise 0

Replace Academic $=1$ if the academic replaces an academic director on the board; otherwise 0

Replace Connected Academic $=1$ if the institution employing the appointed academic is the same as a replaced academic; otherwise 0

Replace Director $=1$ if the academic is replacing another member of the board; otherwise 0

Retired Academic $=1$ if the academic is retired or emeritus at appointment; otherwise 0

Top 25 University $=1$ if the academic's school is ranked in the top 25 schools by the U.S. News \& World Report (2008); otherwise 0

Total Compensation = total of cash, stock and option awards, and other compensation (not available before December 15, 2006)

Unless denoted by ${ }^{*},{ }^{* *}$, or ${ }^{* * * *}$, all measurements are at appointment. ${ }^{*}{ }^{* *}$ ) denotes variable is estimated at fiscal (calendar) year-end prior to appointment.

denotes variable is estimated over the one-year period ending 25 days prior to the announcement date of the academic director appointment. 


\section{References}

Adams, R. B. 2003. What Do Boards Do? Evidence from Board Committee and Director Compensation Data. Working paper, University of Queensland.

Adams, R. B., and H. Mehran. 2003. Is Corporate Governance Different for Bank Holding Companies? Economic Policy Review 9(1):123-42.

Adams, R. B., and D. Ferreira. 2007. A Theory of Friendly Boards. Journal of Finance 62(1):217-50.

Adams, R. B., and D. Ferreira. 2008. Do Directors Perform for Pay? Journal of Accounting and Economics 46(1):154-71.

Adams, R. B., and D. Ferreira. 2009. Women in the Boardroom and Their Impact on Governance and Performance. Journal of Financial Economics 94(2):291-309.

Adams, R. B., B. E. Hermalin, and M.S. Weisbach. 2010. The Role of Boards of Directors in Corporate Governance: A Conceptual Framework and Survey. Journal of Economic Literature 48(1):58-107.

Agrawal, A., and M. A. Chen. 2011. Boardroom Brawls: An Empirical Analysis of Disputes Involving Directors. Working paper, University of Alabama.

Alam, Z. S., M. A. Chen, C. S. Ciccotello, and H. E. Ryan, Jr. 2013. Does the Location of Directors Matter? Information Acquisition and Board Decisions. Journal of Financial and Quantitative Analysis, forthcoming.

Anderson, R. C., D. M. Reeb, A. Upadhyay, and W. Zhao. 2011. The Economics of Director Heterogeneity. Financial Management 40(1):5-38.

Audretsch, D. B., and E. Lehmann. 2006. Entrepreneurial Access and Absorption of Knowledge Spillovers: Strategic Board and Managerial Composition for Competitive Advantage. Journal of Small Business Management 44(2):155-66.

Audretsch, D., and P. E. Stephan. 1996. Company-Scientist Locational Links: The Case of Biotechnology. American Economic Review 86(3):641-52.

Boone, A. L., L. C. Field, J. M. Karpoff, and C. G. Raheja. 2007. The Determinants of Corporate Board Size and Composition: An Empirical Analysis. Journal of Financial Economics 85(1): 66-101.

Brickley, J. A., J. L. Coles, and R. L. Terry. 1994. Outside Directors and the Adoption of Poison Pills. Journal of Financial Economics 35(3):371-90. 
Carrell, S. E., M. E. Page, and J. E. West. 2010. Sex and Science: How Professor Gender Perpetuates the Gender Gap. Quarterly Journal of Economics 125(3):1101-44.

Coles, J. L., N. D. Daniel, and L. Naveen. 2008. Boards: Does One Size Fit All? Journal of Financial Economics 87(2):329-56.

Coles, J. L., N. D. Daniel, and L. Naveen. 2012. Board Advising. Working paper, Arizona State University.

Daily, C. M., and C. Schwenk. 1996. Chief Executive Officers, Top Management Teams and Boards of Directors: Congruent or Countervailing Forces? Journal of Management 22(2):185-202.

Duchin, R., J. G. Matsusaka, and O. Ozbas. 2010. When Are Outside Directors Effective? Journal of Financial Economics 96(2):195-214.

Fama, E. F., and K. R. French. 1997. Industry Costs of Equity. Journal of Financial Economics 43(2):153-93.

Fama, E. F., and M. C. Jensen. 1983. Separation of Ownership and Control. Journal of Law and Economics 26(2):301-25.

Fich, E. 2005. Are Some Outside Directors Better Than Others? Evidence from Director Appointments by Fortune 1000 Firms. Journal of Business 78(5):1943-71.

Fich, E. M., and A. Shivdasani. 2006. Are Busy Boards Effective Monitors? Journal of Finance 61(2):689-724.

Francis, B., I. Hasan, and Q. Wu. 2011. Professors in the Boardroom: Is There an Added Value for Academic Directors? Working paper, Rensselaer Polytechnic Institute.

Goldman, E., J. Rocholl, and J. So. 2009. Do Politically Connected Boards Affect Firm Value? Review of Financial Studies 22(6):2331-60.

Gompers, P., J. Ishii, and A. Metrick. 2003. Corporate Governance and Equity Prices. Quarterly Journal of Economics 118(1):107-55.

Gulati, R., and M. Gargiulo. 1999. Where Do Interorganizational Networks Come From? American Journal of Sociology 104(5):1439-93.

Guner, A. B., U. Malmendier, and G. Tate. 2008. Financial Expertise of Directors. Journal of Financial Economics 88(2):323-54.

Hambrick, D. C., and R. A. D’Aveni. 1992. Top Team Deterioration as Part of the Downward Spiral of Large Corporate Bankruptcies. Management Science 38(10):1445-66. 
Hwang, B. H., and S. Kim. 2009. It Pays to Have Friends. Journal of Financial Economics 93(1):138-58.

Lehn, K., S. Patro, and M. Zhao. 2009. Determinants of the Size and Structure of Corporate Boards: 1935-2000. Financial Management 38(4):747-80.

Linck, J. S., J. M. Netter, and T. Yang. 2008. The Determinants of Board Structure. Journal of Financial Economics 87(2):308-28.

Linck, J. S., J. M. Netter, and T. Yang. 2009. The Effects and Unintended Consequences of the Sarbanes-Oxley Act on the Supply and Demand for Directors. Review of Financial Studies 22(8):3287-3328.

Lynall, M. D., B. R. Golden, and A. J. Hillman. 2003. Board Composition from Adolescence to Maturity: A Multitheoretic View. Academy of Management Review 28(3):416-31.

Mattis, M. C. 2000. Women Corporate Directors in the United States, in R. Burke and M. Mattis (eds), Women on Corporate Boards of Directors. Netherlands: Kluwer Academic.

Ravina, E., and P. Sapienza. 2010. What Do Independent Directors Know? Evidence from Their Trading. Review of Financial Studies 23(3):962-1003.

Rosenstein, S., and J. G. Wyatt. 1990. Outside Directors, Board Independence and Shareholder Wealth. Journal of Financial Economics 26(2):175-91.

Shivdasani, A., and D. Yermack. 1999. CEO Involvement in the Selection of New Board Members: An Empirical Analysis. Journal of Finance 54(5):1829-53.

Singh, V., S. Terjesen, and S. Vinnicombe. 2008. Newly Appointed Directors in the Boardroom: How Do Women and Men Differ? European Management Journal 26(1):48-58.

Trautman, L. 2012. The Matrix: The Board's Responsibility for Director Selection and Recruitment. Florida State University Business Review 11(1):1-66.

Vafeas, N. 1999. The Nature of Board Nominating Committees and Their Role in Corporate Governance. Journal of Business Finance and Accounting 26(1-2):199-225.

Weisbach, M. S. 1988. Outside Directors and CEO Turnover. Journal of Financial Economics 20(1-2):431-60.

Westphal, J. 1999. Collaboration in the Boardroom: Behavioral and Performance Consequences of CEO-Board Social Ties. Academy of Management Journal 42(1):7-25. 
Table 1

Distribution of Academic Director Appointments by Year and Classification

\begin{tabular}{|c|c|c|c|c|c|c|c|c|}
\hline \multirow[b]{2}{*}{$\begin{array}{l}\text { Proxy } \\
\text { Year }\end{array}$} & \multicolumn{2}{|c|}{ Total } & \multicolumn{2}{|c|}{ Administrative } & \multicolumn{2}{|c|}{ Business } & \multicolumn{2}{|c|}{ Specialized } \\
\hline & Frequency & $\begin{array}{c}\text { Non-meeting } \\
\text { Appointment } \\
\text { Percentage }\end{array}$ & Frequency & $\begin{array}{c}\text { Percent of } \\
\text { Total }\end{array}$ & Frequency & $\begin{array}{c}\text { Percent of } \\
\text { Total }\end{array}$ & Frequency & $\begin{array}{c}\text { Percent of } \\
\text { Total }\end{array}$ \\
\hline Late 1995 & 20 & 45.00 & 11 & 55.00 & 4 & 20.00 & 5 & 25.00 \\
\hline 1996 & 29 & 58.62 & 16 & 55.17 & 9 & 31.03 & 4 & 13.79 \\
\hline 1997 & 53 & 81.13 & 29 & 54.72 & 14 & 26.42 & 10 & 18.87 \\
\hline 1998 & 42 & 76.19 & 23 & 54.76 & 12 & 28.57 & 7 & 16.67 \\
\hline 1999 & 37 & 78.38 & 24 & 64.86 & 12 & 32.43 & 1 & 2.70 \\
\hline 2000 & 34 & 85.29 & 21 & 61.76 & 8 & 23.53 & 5 & 14.71 \\
\hline 2001 & 43 & 79.07 & 22 & 51.16 & 13 & 30.23 & 8 & 18.60 \\
\hline 2002 & 56 & 85.71 & 39 & 69.64 & 10 & 17.86 & 7 & 12.50 \\
\hline 2003 & 52 & 76.92 & 34 & 65.38 & 14 & 26.92 & 4 & 7.69 \\
\hline 2004 & 63 & 79.37 & 37 & 58.73 & 19 & 30.16 & 7 & 11.11 \\
\hline 2005 & 47 & 63.83 & 30 & 63.83 & 12 & 25.53 & 5 & 10.64 \\
\hline 2006 & 34 & 88.24 & 25 & 73.53 & 6 & 17.65 & 3 & 8.82 \\
\hline 2007 & 33 & 69.70 & 20 & 60.61 & 6 & 18.18 & 7 & 21.21 \\
\hline Early 2008 & 7 & 100.00 & 1 & 14.29 & 4 & 57.14 & 2 & 28.57 \\
\hline Total & 550 & 76.36 & 332 & 60.36 & 143 & 26.00 & 75 & 13.64 \\
\hline
\end{tabular}

This table presents the yearly distribution for 550 academic director appointments in this study. We report appointments by proxy year and director classification. Non-meeting appointments are announced prior to the proxy filing or mailing date and the annual shareholder meeting. Classification of academic appointments are as follows: Administrative - academics with administrative leadership positions, including presidents, chancellors, deans, provosts, vice presidents, chief operating officers, and directors of special centers; Business - academics with general business expertise, including business and law professors; and Specialized - academics with specialized expertise, including medicine, chemistry, physics, biology, and engineering professors. 
Table 2

Academic Director School Affiliation

\begin{tabular}{|c|c|c|c|c|}
\hline & \multicolumn{3}{|c|}{ Appointments } & \multirow{2}{*}{$\begin{array}{c}\text { Distinct } \\
\text { Directors }\end{array}$} \\
\hline & Number & Percent & Cumulative & \\
\hline Harvard University & 78 & 14.2 & 14.2 & 48 \\
\hline Stanford University & 24 & 4.4 & 18.5 & 20 \\
\hline Massachusetts Institute of Tech. & 21 & 3.8 & 22.4 & 14 \\
\hline University of California, Berkeley & 16 & 2.9 & 25.3 & 12 \\
\hline Northwestern University & 15 & 2.7 & 28.0 & 9 \\
\hline University of Pennsylvania & 15 & 2.7 & 30.7 & 8 \\
\hline University of Texas & 12 & 2.2 & 32.9 & 8 \\
\hline Duke University & 12 & 2.2 & 35.1 & 6 \\
\hline Columbia University & 10 & 1.8 & 36.9 & 8 \\
\hline Vanderbilt University & 10 & 1.8 & 38.7 & 5 \\
\hline Johns Hopkins University & 9 & 1.6 & 40.4 & 8 \\
\hline University of Michigan & 9 & 1.6 & 42.0 & 8 \\
\hline Rensselaer Polytechnic Institute & 9 & 1.6 & 43.6 & 1 \\
\hline University of Chicago & 8 & 1.5 & 45.1 & 6 \\
\hline University of Southern California & 8 & 1.5 & 46.6 & 6 \\
\hline Texas A\&M University & 8 & 1.5 & 48.0 & 5 \\
\hline Drexel University & 8 & 1.5 & 49.5 & 2 \\
\hline Yale University & 7 & 1.3 & 50.7 & 6 \\
\hline The Ohio State University & 7 & 1.3 & 52.0 & 5 \\
\hline Princeton University & 7 & 1.3 & 53.3 & 5 \\
\hline University of North Carolina & 6 & 1.1 & 54.4 & 6 \\
\hline Cornell University & 6 & 1.1 & 55.5 & 4 \\
\hline Georgetown University & 6 & 1.1 & 56.6 & 4 \\
\hline New York University & 5 & 0.9 & 57.5 & 5 \\
\hline Dartmouth College & 5 & 0.9 & 58.4 & 3 \\
\hline Indiana University & 5 & 0.9 & 59.3 & 2 \\
\hline (9) Schools & 4 & 6.6 & 65.8 & -- \\
\hline (21) Schools & 3 & 11.5 & 77.3 & -- \\
\hline (27) Schools & 2 & 9.8 & 87.1 & -- \\
\hline (71) Schools & 1 & 12.9 & 100.0 & -- \\
\hline Total & 550 & & & 372 \\
\hline
\end{tabular}

This table presents the institutional representation for the sample of 550 academic director appointments of 372 distinct individuals. 
Table 3

Appointing Firm and Board Characteristics

\begin{tabular}{|c|c|c|c|c|}
\hline & $\begin{array}{c}\text { Full Sample } \\
\mathbf{N}=\mathbf{5 5 0}\end{array}$ & $\begin{array}{l}\text { Admin } \\
\mathrm{N}=332\end{array}$ & $\begin{array}{c}\text { Business } \\
\mathrm{N}=143\end{array}$ & $\begin{array}{c}\text { Specialized } \\
\mathrm{N}=75\end{array}$ \\
\hline \multicolumn{5}{|l|}{ Panel A. Firm Characteristics } \\
\hline Small Cap (\%) & 37.64 & 35.24 & $44.06^{\mathrm{c}}$ & 36.00 \\
\hline Mid Cap (\%) & 35.84 & 35.84 & 33.57 & 36.00 \\
\hline Large Cap (\%) & 28.92 & 28.92 & 22.38 & 28.00 \\
\hline Market Capitalization (\$M) & $12,426.03^{+}$ & $11,240.99$ & $13,145.18$ & $16,300.68$ \\
\hline Total Assets (\$M) & $9,703.44$ & $10,644.55$ & $9,266.02$ & $6,371.49$ \\
\hline Sales (\$M) & $6,850.02$ & $6,402.01$ & $8,759.39$ & $5,192.66$ \\
\hline Number of Shareholders (M) & 47.22 & 53.48 & 40.99 & 31.31 \\
\hline Firm Age (years) & 21.94 & $23.60^{\mathrm{b}}$ & $18.25^{\mathrm{b}}$ & 21.67 \\
\hline Inside Ownership (\%) & 3.39 & 3.17 & 4.40 & 2.28 \\
\hline Institutional Ownership (\%) & 59.53 & $61.29^{\mathrm{b}}$ & 59.15 & $52.49^{\mathrm{a}}$ \\
\hline NYSE Listing (\%) & 67.27 & $73.49^{\mathrm{a}}$ & 62.94 & $48.00^{\mathrm{a}}$ \\
\hline Short-Term Debt (\%) & 3.94 & $4.39^{\mathrm{b}}$ & $3.01^{\mathrm{b}}$ & 3.71 \\
\hline Long-Term Debt (\%) & 19.69 & 20.46 & 19.38 & 16.84 \\
\hline G-Index & 9.06 & 9.20 & 8.92 & 8.57 \\
\hline Free Cash Flow (\%) & $5.46^{-}$ & $6.55^{\mathrm{b}}$ & 6.50 & $-1.23^{\mathrm{a}}$ \\
\hline Cash-to-Assets (\%) & $16.83^{+}$ & $14.44^{\mathrm{a}}$ & 15.50 & $29.97^{\mathrm{a}}$ \\
\hline Prior Operating Performance (\%) & 11.02 & $12.16^{\mathrm{b}}$ & 12.33 & $3.50^{\mathrm{a}}$ \\
\hline Prior 1-Year Return (\%) & $28.73^{+}$ & 31.21 & 24.58 & 25.49 \\
\hline Prior 1-Year Adjusted Return (\%) & $-0.35^{+}$ & 2.13 & -5.18 & -2.20 \\
\hline Tobin’s Q & 2.40 & 2.34 & 2.36 & $2.78^{\mathrm{c}}$ \\
\hline Prior Sales Growth (\%) & $26.63^{+}$ & 24.11 & 16.74 & $57.45^{\mathrm{b}}$ \\
\hline R\&D Intensity (\%) & 4.63 & $3.84^{\mathrm{b}}$ & $2.96^{\mathrm{b}}$ & $11.36^{\mathrm{a}}$ \\
\hline Advertising Intensity (\%) & $1.75^{+}$ & 1.56 & $2.55^{\mathrm{b}}$ & 1.03 \\
\hline SG\&A Intensity (\%) & 23.62 & $21.84^{\mathrm{b}}$ & $29.75^{\mathrm{a}}$ & 19.84 \\
\hline Firm Risk $(\%)$ & 2.90 & 2.82 & 2.98 & 3.13 \\
\hline \multicolumn{5}{|l|}{ Panel B. Board Characteristics } \\
\hline Board Size & 9.25 & $9.42^{\mathrm{c}}$ & $8.85^{\mathrm{b}}$ & 9.27 \\
\hline Independent Directors (\%) & 63.12 & 64.06 & 61.92 & 61.26 \\
\hline Employee Directors (\%) & $24.43^{+}$ & 23.54 & 26.14 & 25.09 \\
\hline Captured Directors (\%) & $55.18^{+}$ & 53.23 & 58.01 & 58.38 \\
\hline Classified Board (\%) & 58.91 & 59.04 & 58.74 & 58.67 \\
\hline CEO Nominating Committee (\%) & 30.73 & 28.61 & 34.97 & 32.00 \\
\hline CEO is Chair (\%) & 70.00 & 68.98 & 72.03 & 70.67 \\
\hline Existing Academic on Board (\%) & $48.00^{+}$ & 45.78 & 42.66 & $68.00^{\mathrm{a}}$ \\
\hline Existing Academic Directors & $0.76^{+}$ & 0.70 & 0.64 & $1.24^{\mathrm{a}}$ \\
\hline
\end{tabular}


Table 4

Academic Director and Appointment Characteristics

\begin{tabular}{|c|c|c|c|c|c|}
\hline & $\begin{array}{c}\text { First } \\
\text { Appointment } \\
\text { N=372 } \\
\end{array}$ & $\begin{array}{c}\text { Full } \\
\text { Sample } \\
\mathrm{N}=\mathbf{5 5 0} \\
\end{array}$ & $\begin{array}{l}\text { Admin } \\
\mathbf{N}=332\end{array}$ & $\begin{array}{c}\text { Business } \\
\mathrm{N}=143 \\
\end{array}$ & $\begin{array}{c}\text { Specialized } \\
\mathrm{N}=75\end{array}$ \\
\hline \multicolumn{6}{|l|}{ Panel A. Director Characteristics } \\
\hline Age (years) & 56.01 & 55.99 & $56.61^{\mathrm{b}}$ & $53.78^{\mathrm{a}}$ & $57.43^{\mathrm{c}}$ \\
\hline Academia (\%) & 90.59 & 87.82 & 87.95 & 88.81 & 85.33 \\
\hline Retired Academic (\%) & 7.26 & 8.91 & 9.64 & 10.49 & $2.67^{\mathrm{b}}$ \\
\hline Female $(\%)$ & 19.89 & 21.64 & $24.10^{\mathrm{c}}$ & 21.68 & $10.67^{\mathrm{b}}$ \\
\hline Independent (\%) & 95.70 & 97.09 & 97.89 & 96.50 & 94.67 \\
\hline Directorships & 0.82 & 1.34 & 1.41 & 1.48 & $0.77^{\mathrm{b}}$ \\
\hline Busy Director (\%) & 17.74 & 31.64 & $34.34^{\mathrm{c}}$ & 32.87 & $17.33^{\mathrm{a}}$ \\
\hline Private University (\%) & 63.98 & 66.73 & $61.45^{\mathrm{a}}$ & $75.52^{\mathrm{a}}$ & 73.33 \\
\hline Top 25 University (\%) & 54.57 & 55.09 & $43.67^{\mathrm{a}}$ & $74.13^{\mathrm{a}}$ & $69.33^{\mathrm{a}}$ \\
\hline Ivy League (\%) & 22.04 & 23.64 & $12.95^{\mathrm{a}}$ & $44.06^{\mathrm{a}}$ & $32.00^{\mathrm{c}}$ \\
\hline Business School (\%) & 37.63 & 39.45 & $27.71^{\mathrm{a}}$ & $87.41^{\mathrm{a}}$ & $0.00^{\mathrm{a}}$ \\
\hline Financial Expert $(\%)$ & 4.84 & 4.36 & 3.92 & $7.69^{\mathrm{b}}$ & $0.00^{\mathrm{b}}$ \\
\hline \multicolumn{6}{|l|}{ Panel B. Director Connections } \\
\hline CEO Direct $(\%)$ & 12.10 & 11.27 & $9.34^{\mathrm{c}}$ & $16.08^{\mathrm{b}}$ & 10.67 \\
\hline CEO Indirect (\%) & 16.13 & 16.00 & 14.46 & $21.68^{\mathrm{b}}$ & 12.00 \\
\hline Existing Acad. Connection (\%) & 7.53 & 7.45 & $5.72^{\mathrm{c}}$ & 9.79 & 10.67 \\
\hline Replace Connected Acad. (\%) & 2.69 & 1.82 & 1.51 & 2.80 & 1.33 \\
\hline Distance (miles) & 613.32 & 623.33 & $507.28^{\mathrm{a}}$ & $797.49^{\mathrm{a}}$ & $804.97^{\mathrm{b}}$ \\
\hline \multicolumn{6}{|c|}{ Panel C. Appointment Characteristics } \\
\hline Expanding Board (\%) & $62.63^{+}$ & $64.55^{+}$ & 64.26 & 63.38 & 69.33 \\
\hline Replace Director (\%) & $40.32^{+}$ & $38.00^{+}$ & 38.14 & 38.03 & 36.00 \\
\hline Replace Academic (\%) & $8.87^{+}$ & $7.45^{+}$ & 6.33 & 6.99 & $13.33^{\mathrm{b}}$ \\
\hline Key Committee Appoint. (\%) & 45.43 & 45.27 & 47.59 & 44.06 & 37.33 \\
\hline Audit (\%) & 28.76 & 27.82 & 29.82 & 30.07 & $13.33^{\mathrm{a}}$ \\
\hline Compensation $(\%)$ & 14.52 & 15.45 & 14.76 & 17.48 & 14.67 \\
\hline Corporate Governance (\%) & 13.44 & 16.00 & 15.06 & 13.29 & 13.33 \\
\hline Nominating $(\%)$ & 15.05 & 15.82 & 16.57 & 11.89 & 14.67 \\
\hline \multicolumn{6}{|c|}{ Panel D. Total Compensation (\$000s) } \\
\hline Fiscal Year 2006 & & 171.0 & 362.5 & 172.6 & 227.9 \\
\hline Fiscal Year 2007 & & 182.1 & 375.4 & 175.4 & 255.4 \\
\hline Fiscal Year 2008 & & 189.3 & 381.1 & 207.3 & 164.3 \\
\hline Fiscal Year 2009 & & 180.3 & 449.2 & 166.0 & 228.4 \\
\hline
\end{tabular}


Table 5

Most Frequently Appointed Academic Directors

\begin{tabular}{|c|c|c|c|c|c|}
\hline Academic Director & Title & $\begin{array}{l}\text { Academic Institution(s) } \\
\text { at Appointment }\end{array}$ & Classification & $\begin{array}{l}\text { Appointments } \\
\text { in Sample }\end{array}$ & $\begin{array}{l}\text { Max Other } \\
\text { Boards at } \\
\text { Appointment } \\
\end{array}$ \\
\hline Shirley A. Jackson & President & $\begin{array}{l}\text { Rensselaer Polytechnic } \\
\text { Institute }\end{array}$ & Admin & 9 & 8 \\
\hline John M. Deutch & Professor, Chemistry & $\begin{array}{l}\text { Massachusetts Institute of } \\
\text { Technology }\end{array}$ & Specialized & 7 & 6 \\
\hline James I. Cash, Jr. & Professor, Business & Harvard University & Business & 7 & 5 \\
\hline Thomas P. Gerrity & Dean, Business & University of Pennsylvania & Admin & 6 & 6 \\
\hline Constantine N. Papadakis & President & Drexel University & Admin & 5 & 5 \\
\hline Kristina M. Johnson & Dean, Engineering & Duke University & Admin & 5 & 3 \\
\hline Charles M. Elson & Professor, Law & $\begin{array}{l}\text { Stetson University / } \\
\text { University of Delaware }\end{array}$ & Business & 5 & 3 \\
\hline John Rau & Dean, Business & Indiana University & Admin & 4 & 4 \\
\hline S. Malcolm Gillis & President & Rice University & Admin & 4 & 3 \\
\hline Pamela S. Lewis & $\begin{array}{l}\text { Dean, Business / } \\
\text { President }\end{array}$ & $\begin{array}{l}\text { Drexel University / } \\
\text { Queens College }\end{array}$ & Admin & 4 & 2 \\
\hline
\end{tabular}

This table presents the names, titles, academic affiliation, classification and the number of appointing boards for the ten most frequently appointed academic directors in our sample. The last column presents the maximum number of other public directorships at appointment. 
Table 6

Likelihood of Academic Director Appointment

\begin{tabular}{|c|c|c|c|c|c|c|}
\hline & \multicolumn{3}{|c|}{ Multinomial Logit } & \multicolumn{3}{|c|}{ Logit } \\
\hline & $\begin{array}{c}(1) \\
\text { Admin }\end{array}$ & $\begin{array}{c}(2) \\
\text { Business }\end{array}$ & $\begin{array}{c}(3) \\
\text { Specialized }\end{array}$ & $\begin{array}{c}(4) \\
\text { Admin }\end{array}$ & $\begin{array}{c}(5) \\
\text { Business }\end{array}$ & $\begin{array}{c}(6) \\
\text { Specialized }\end{array}$ \\
\hline Intercept & $\begin{array}{l}-1.53 \\
(0.13)\end{array}$ & $\begin{array}{l}-1.62 \\
(0.20)\end{array}$ & $\begin{array}{l}-0.74 \\
(0.69)\end{array}$ & $\begin{array}{l}-0.98 \\
(0.43)\end{array}$ & $\begin{array}{l}-0.42 \\
(0.75)\end{array}$ & $\begin{array}{l}-0.50 \\
(0.77)\end{array}$ \\
\hline Top 25 University & & & & $\begin{array}{l}-1.30^{* * *} \\
(0.00)\end{array}$ & $\begin{array}{l}1.33^{* * *} \\
(0.00)\end{array}$ & $\begin{array}{l}0.64^{* *} \\
(0.05)\end{array}$ \\
\hline CEO Connection & & & & $\begin{array}{l}-0.16 \\
(0.60)\end{array}$ & $\begin{array}{c}0.31 \\
(0.33)\end{array}$ & $\begin{array}{l}-0.21 \\
(0.67)\end{array}$ \\
\hline Long Distance & & & & $\begin{array}{l}-0.40^{*} \\
(0.05)\end{array}$ & $\begin{array}{l}0.64^{* * *} \\
(0.00)\end{array}$ & $\begin{array}{l}-0.16 \\
(0.58)\end{array}$ \\
\hline Board Size & $\begin{array}{c}-0.28 \\
(0.39)\end{array}$ & $\begin{array}{l}-0.52 \\
(0.19)\end{array}$ & $\begin{array}{l}-0.23 \\
(0.67)\end{array}$ & $\begin{array}{c}0.45 \\
(0.25)\end{array}$ & $\begin{array}{l}-0.73^{*} \\
(0.08)\end{array}$ & $\begin{array}{c}0.27 \\
(0.63)\end{array}$ \\
\hline Existing Academic on Board & $\begin{array}{l}0.97^{* * *} \\
(0.00)\end{array}$ & $\begin{array}{l}0.94^{* * *} \\
(0.00)\end{array}$ & $\begin{array}{l}1.74^{* * *} \\
(0.00)\end{array}$ & $\begin{array}{l}-0.25 \\
(0.22)\end{array}$ & $\begin{array}{l}-0.09 \\
(0.69)\end{array}$ & $\begin{array}{l}0.66^{* *} \\
(0.04)\end{array}$ \\
\hline Captured Directors & $\begin{array}{c}0.02^{* * * *} \\
(0.00)\end{array}$ & $\begin{array}{l}0.02^{\text {**** }} \\
(0.00)\end{array}$ & $\begin{array}{c}0.02^{* * *} \\
(0.00)\end{array}$ & $\begin{array}{l}-0.00 \\
(0.96)\end{array}$ & $\begin{array}{l}-0.00 \\
(0.98)\end{array}$ & $\begin{array}{c}0.00 \\
(0.95)\end{array}$ \\
\hline Independent Directors & $\begin{array}{c}0.00 \\
(0.90)\end{array}$ & $\begin{array}{c}0.00 \\
(0.77)\end{array}$ & $\begin{array}{l}-0.01 \\
(0.24)\end{array}$ & $\begin{array}{c}0.01 \\
(0.36)\end{array}$ & $\begin{array}{l}-0.00 \\
(0.93)\end{array}$ & $\begin{array}{l}-0.01 \\
(0.32)\end{array}$ \\
\hline Employee Directors & $\begin{array}{c}0.01 \\
(0.32)\end{array}$ & $\begin{array}{c}0.01 \\
(0.12)\end{array}$ & $\begin{array}{l}-0.00 \\
(0.76)\end{array}$ & $\begin{array}{l}-0.00 \\
(0.90)\end{array}$ & $\begin{array}{c}0.01 \\
(0.31)\end{array}$ & $\begin{array}{l}-0.01 \\
(0.36)\end{array}$ \\
\hline Classified Board & $\begin{array}{c}0.02 \\
(0.88)\end{array}$ & $\begin{array}{c}0.05 \\
(0.80)\end{array}$ & $\begin{array}{c}0.09 \\
(0.74)\end{array}$ & $\begin{array}{l}-0.02 \\
(0.91)\end{array}$ & $\begin{array}{c}0.08 \\
(0.73)\end{array}$ & $\begin{array}{c}0.03 \\
(0.91)\end{array}$ \\
\hline CEO is Chair & $\begin{array}{c}-0.56^{* * * *} \\
(0.00)\end{array}$ & $\begin{array}{l}-0.31 \\
(0.21)\end{array}$ & $\begin{array}{l}-0.25 \\
(0.41)\end{array}$ & $\begin{array}{l}-0.37^{*} \\
(0.10)\end{array}$ & $\begin{array}{c}0.25 \\
(0.35)\end{array}$ & $\begin{array}{c}0.34 \\
(0.29)\end{array}$ \\
\hline NYSE & $\begin{array}{l}0.82^{* * * *} \\
(0.00)\end{array}$ & $\begin{array}{l}0.44^{*} \\
(0.10)\end{array}$ & $\begin{array}{l}-0.18 \\
(0.67)\end{array}$ & $\begin{array}{c}0.50^{*} \\
(0.09)\end{array}$ & $\begin{array}{l}-0.29 \\
(0.32)\end{array}$ & $\begin{array}{l}-0.79^{*} \\
(0.08)\end{array}$ \\
\hline Firm Age & $\begin{array}{l}-0.00 \\
(0.39)\end{array}$ & $\begin{array}{l}-0.01^{*} \\
(0.10)\end{array}$ & $\begin{array}{c}0.01 \\
(0.40)\end{array}$ & $\begin{array}{c}0.00 \\
(0.73)\end{array}$ & $\begin{array}{l}-0.01 \\
(0.28)\end{array}$ & $\begin{array}{c}0.01 \\
(0.12)\end{array}$ \\
\hline Small Cap & $\begin{array}{l}-0.06 \\
(0.77)\end{array}$ & $\begin{array}{l}-0.06 \\
(0.82)\end{array}$ & $\begin{array}{c}-0.91^{* *} \\
(0.01)\end{array}$ & $\begin{array}{c}0.18 \\
(0.49)\end{array}$ & $\begin{array}{c}0.15 \\
(0.57)\end{array}$ & $\begin{array}{l}-0.70^{*} \\
(0.06)\end{array}$ \\
\hline Large Cap & $\begin{array}{c}0.15 \\
(0.47)\end{array}$ & $\begin{array}{c}0.30 \\
(0.31)\end{array}$ & $\begin{array}{l}-0.07 \\
(0.85)\end{array}$ & $\begin{array}{c}0.08 \\
(0.76)\end{array}$ & $\begin{array}{c}0.13 \\
(0.68)\end{array}$ & $\begin{array}{l}-0.22 \\
(0.56)\end{array}$ \\
\hline Institutional Ownership & $\begin{array}{c}0.50 \\
(0.22)\end{array}$ & $\begin{array}{l}-0.01 \\
(0.98)\end{array}$ & $\begin{array}{l}-1.25^{*} \\
(0.09)\end{array}$ & $\begin{array}{l}1.10^{* *} \\
(0.02)\end{array}$ & $\begin{array}{l}-0.52 \\
(0.34)\end{array}$ & $\begin{array}{c}-1.82^{* *} \\
(0.01)\end{array}$ \\
\hline Cash-to-Assets & $\begin{array}{c}0.48 \\
(0.40)\end{array}$ & $\begin{array}{c}0.37 \\
(0.59)\end{array}$ & $\begin{array}{l}2.28^{* * *} \\
(0.00)\end{array}$ & $\begin{array}{c}0.20 \\
(0.77)\end{array}$ & $\begin{array}{l}-1.11 \\
(0.15)\end{array}$ & $\begin{array}{c}1.38 \\
(0.13)\end{array}$ \\
\hline
\end{tabular}




\begin{tabular}{|c|c|c|c|c|c|c|}
\hline R\&D Intensity & $\begin{array}{l}-0.48 \\
(0.72)\end{array}$ & $\begin{array}{l}-4.22^{*} \\
(0.10)\end{array}$ & $\begin{array}{c}0.80 \\
(0.57)\end{array}$ & $\begin{array}{c}0.16 \\
(0.92)\end{array}$ & $\begin{array}{l}-5.89^{*} \\
(0.07)\end{array}$ & $\begin{array}{c}2.22 \\
(0.48)\end{array}$ \\
\hline Advertising Intensity & $\begin{array}{c}4.42^{*} \\
(0.07)\end{array}$ & $\begin{array}{l}5.80^{* *} \\
(0.01)\end{array}$ & $\begin{array}{l}-0.84 \\
(0.85)\end{array}$ & $\begin{array}{l}-0.81 \\
(0.70)\end{array}$ & $\begin{array}{c}2.28 \\
(0.28)\end{array}$ & $\begin{array}{l}-5.31 \\
(0.20)\end{array}$ \\
\hline SG\&A Intensity & $\begin{array}{l}-0.23 \\
(0.57)\end{array}$ & $\begin{array}{l}0.94^{* *} \\
(0.05)\end{array}$ & $\begin{array}{c}0.04 \\
(0.95)\end{array}$ & $\begin{array}{l}-0.52 \\
(0.30)\end{array}$ & $\begin{array}{c}1.09^{*} \\
(0.06)\end{array}$ & $\begin{array}{l}-0.34 \\
(0.67)\end{array}$ \\
\hline Short-Term Debt & $\begin{array}{c}1.88 \\
(0.14)\end{array}$ & $\begin{array}{l}-1.91 \\
(0.33)\end{array}$ & $\begin{array}{c}0.59 \\
(0.81)\end{array}$ & $\begin{array}{c}7.23 \\
(0.33)\end{array}$ & $\begin{array}{c}0.25 \\
(0.98)\end{array}$ & $\begin{array}{l}-16.01 \\
(0.21)\end{array}$ \\
\hline Firm Risk & $\begin{array}{l}-1.42 \\
(0.80)\end{array}$ & $\begin{array}{l}-6.81 \\
(0.36)\end{array}$ & $\begin{array}{c}-21.69^{*} \\
(0.05)\end{array}$ & $\begin{array}{c}7.23 \\
(0.33)\end{array}$ & $\begin{array}{c}0.25 \\
(0.98)\end{array}$ & $\begin{array}{r}-16.01 \\
(0.21)\end{array}$ \\
\hline Prior Operating Performance & $\begin{array}{l}-0.77 \\
(0.26)\end{array}$ & $\begin{array}{l}-0.98 \\
(0.29)\end{array}$ & $\begin{array}{l}-1.52 \\
(0.16)\end{array}$ & $\begin{array}{c}0.80 \\
(0.31)\end{array}$ & $\begin{array}{c}0.34 \\
(0.74)\end{array}$ & $\begin{array}{l}-1.47 \\
(0.23)\end{array}$ \\
\hline SOX & $\begin{array}{l}-0.18 \\
(0.31)\end{array}$ & $\begin{array}{l}-0.08 \\
(0.74)\end{array}$ & $\begin{array}{l}-0.72^{* *} \\
(0.03)\end{array}$ & $\begin{array}{l}-0.00 \\
(0.99)\end{array}$ & $\begin{array}{c}0.35 \\
(0.15)\end{array}$ & $\begin{array}{l}-0.58^{*} \\
(0.06)\end{array}$ \\
\hline & \multicolumn{3}{|c|}{ Appointing and Match Firms } & \multicolumn{3}{|c|}{ Appointing Firms } \\
\hline Observations & & 1100 & & 550 & 550 & 550 \\
\hline Pseudo $\mathrm{R}^{2}$ & & 0.11 & & 0.11 & 0.14 & 0.16 \\
\hline
\end{tabular}

This table presents results from logit regressions estimating the likelihood of appointing an academic director by type based on firm, board, and director characteristics. Columns (1) to (3) report the results of a multinomial logit model of the choice to appoint a certain type of academic director compared to not appointing an academic based on firm and board characteristics for sample and match firms. The dependent variable equals 1, 2 or 3 if a firm appoints an Admin, Business, or Specialist academic director, and 0 for match firms. Columns (4) to (6) present the results of three logit models of the choice to appoint a certain type of academic conditional on appointing an academic, additionally including academic characteristics as independent variables. The dependent variable equals 1 when the type of academic appointed corresponds to the column type and 0, otherwise. Long Distance equals 1 if the distance is greater than the median value for all sample firms. SOX equals 1 if the director is appointed after 2002. All other variables are defined in the Appendix. The numbers in parentheses are $p$-values for two-sided tests. ${ }^{* * *}$, and ${ }^{* * *}$ denote statistical significance at the $10 \%, 5 \%$, and $1 \%$ levels, respectively. All models employ robust standard errors clustered at the firm level. 
Table 7

Academic Director Appointment Announcement Returns

\begin{tabular}{|c|c|c|c|}
\hline & Admin & Business & Specialized \\
\hline \multicolumn{4}{|c|}{ Panel A. All appointments } \\
\hline $\mathrm{N}$ & 332 & 143 & 75 \\
\hline Mean CAAR $(\%)$ & -0.22 & -0.47 & $0.96^{* *}$ \\
\hline Median CAAR (\%) & 0.06 & -0.11 & 0.09 \\
\hline \multicolumn{4}{|l|}{ Panel B. Business School } \\
\hline $\mathrm{N}$ & 92 & 125 & N/A \\
\hline Mean CAAR (\%) & $0.62^{*}$ & -0.36 & \\
\hline Median CAAR $(\%)$ & $0.55^{* *}$ & -0.11 & \\
\hline \multicolumn{4}{|c|}{ Panel C. Non-Business School } \\
\hline $\mathrm{N}$ & 240 & 18 & 75 \\
\hline Mean CAAR $(\%)$ & $-0.54^{*}$ & -1.23 & $0.96^{* *}$ \\
\hline Median CAAR (\%) & -0.17 & -0.18 & 0.09 \\
\hline \multicolumn{4}{|c|}{ Panel D. Appointments with Close Proximity } \\
\hline $\mathrm{N}$ & 178 & 58 & 39 \\
\hline Mean CAAR $(\%)$ & 0.32 & -0.24 & -0.39 \\
\hline Median CAAR $(\%)$ & 0.21 & -0.06 & -0.75 \\
\hline \multicolumn{4}{|c|}{ Panel E. Appointments with Distant Proximity } \\
\hline $\mathrm{N}$ & 154 & 85 & 36 \\
\hline Mean CAAR (\%) & $-0.83^{*}$ & -0.63 & $2.41^{* * *}$ \\
\hline Median CAAR $(\%)$ & -0.08 & -0.33 & $1.38^{* *}$ \\
\hline \multicolumn{4}{|c|}{ Panel F. Appointments Expanding Board } \\
\hline $\mathrm{N}$ & 204 & 89 & 48 \\
\hline Mean CAAR (\%) & 0.23 & -0.65 & $1.44^{* *}$ \\
\hline Median CAAR $(\%)$ & $0.22^{*}$ & -0.33 & 0.64 \\
\hline \multicolumn{4}{|c|}{ Panel G. Appointments Replacing a Director } \\
\hline $\mathrm{N}$ & 128 & 54 & 27 \\
\hline Mean CAAR (\%) & $-0.93^{* *}$ & -0.18 & -0.09 \\
\hline Median CAAR (\%) & -0.25 & -0.08 & -0.55 \\
\hline
\end{tabular}

This table presents mean and median cumulative abnormal announcement returns (CAARs) for the 550 sample appointments of academic directors. CAARs are calculated employing a market model, estimated over the 255 days ending 46 days prior to the announcement date, using the CRSP equal-weighted index. Two-day CAARs [-1,0] are presented, where the event date (day 0) is the earliest announcement of appointment to the board. Close (Distant) proximity equals 1 if the distance is less than or equal to (greater than) the median value for all sample appointments. All variables are defined in the Appendix. Each panel includes the number of positive and negative CAARs for each category. Statistical significance is based on Patell $z$-values for mean CAARs and the Generalized Sign test for median CAARs. ${ }^{* * *}$, and ${ }^{* * *}$ denote statistical significance at the $10 \%, 5 \%$, and $1 \%$ levels, respectively, using a twotailed test. 
Table 8

Regression of Academic Director Appointment CAARs

\begin{tabular}{|c|c|c|c|c|}
\hline & $\begin{array}{l}\text { (1) } \\
\text { All }\end{array}$ & $\begin{array}{c}(2) \\
\text { Admin }\end{array}$ & $\begin{array}{c}\text { (3) } \\
\text { Business } \\
\end{array}$ & $\begin{array}{c}\text { (4) } \\
\text { Specialized }\end{array}$ \\
\hline Intercept & $\begin{array}{c}-0.01 \\
(0.58)\end{array}$ & $\begin{array}{l}-0.01 \\
(0.68)\end{array}$ & $\begin{array}{c}0.02 \\
(0.57)\end{array}$ & $\begin{array}{l}-0.01 \\
(0.87)\end{array}$ \\
\hline Retired Academic & $\begin{array}{c}0.00 \\
(0.72)\end{array}$ & $\begin{array}{c}0.01 \\
(0.22)\end{array}$ & $\begin{array}{c}0.00 \\
(0.68)\end{array}$ & $\begin{array}{l}-0.03 \\
(0.20)\end{array}$ \\
\hline Female & $\begin{array}{c}0.00 \\
(0.57)\end{array}$ & $\begin{array}{c}0.00 \\
(0.70)\end{array}$ & $\begin{array}{c}0.01 \\
(0.28)\end{array}$ & $\begin{array}{l}-0.02 \\
(0.12)\end{array}$ \\
\hline Busy Director & $\begin{array}{c}0.00 \\
(0.95)\end{array}$ & $\begin{array}{c}0.00 \\
(0.93)\end{array}$ & $\begin{array}{c}0.00 \\
(0.60)\end{array}$ & $\begin{array}{l}-0.02 \\
(0.21)\end{array}$ \\
\hline Private University & $\begin{array}{l}-0.00 \\
(0.73)\end{array}$ & $\begin{array}{c}0.00 \\
(0.39)\end{array}$ & $\begin{array}{l}-0.00 \\
(0.90)\end{array}$ & $\begin{array}{l}-0.04^{* *} \\
(0.05)\end{array}$ \\
\hline Long Distance & $\begin{array}{l}-0.01 \\
(0.16)\end{array}$ & $\begin{array}{l}-0.02^{* *} \\
(0.04)\end{array}$ & $\begin{array}{l}-0.01 \\
(0.34)\end{array}$ & $\begin{array}{l}0.02^{* *} \\
(0.03)\end{array}$ \\
\hline CEO Connection & $\begin{array}{l}-0.02 \\
(0.11)\end{array}$ & $\begin{array}{l}-0.03 \\
(0.25)\end{array}$ & $\begin{array}{l}-0.02^{* *} \\
(0.03)\end{array}$ & $\begin{array}{l}-0.02 \\
(0.26)\end{array}$ \\
\hline Existing Academic & $\begin{array}{c}-0.01 \\
(0.22)\end{array}$ & $\begin{array}{l}-0.00 \\
(0.53)\end{array}$ & $\begin{array}{l}-0.01 \\
(0.22)\end{array}$ & $\begin{array}{l}-0.03 \\
(0.12)\end{array}$ \\
\hline Replace Director & $\begin{array}{l}-0.01^{* *} \\
(0.04)\end{array}$ & $\begin{array}{l}-0.02^{*} \\
(0.06)\end{array}$ & $\begin{array}{l}-0.00 \\
(0.77)\end{array}$ & $\begin{array}{l}-0.01 \\
(0.44)\end{array}$ \\
\hline Replace Academic & $\begin{array}{l}0.02^{* *} \\
(0.02)\end{array}$ & $\begin{array}{l}0.02^{* *} \\
(0.04)\end{array}$ & $\begin{array}{c}0.03 \\
(0.20)\end{array}$ & $\begin{array}{c}0.01 \\
(0.45)\end{array}$ \\
\hline Log Board Size (t-1) & $\begin{array}{l}0.02^{* *} \\
(0.02)\end{array}$ & $\begin{array}{c}0.02 \\
(0.12)\end{array}$ & $\begin{array}{c}0.02 \\
(0.10)\end{array}$ & $\begin{array}{c}0.03 \\
(0.33)\end{array}$ \\
\hline Independent Directors & $\begin{array}{c}0.00 \\
(0.53)\end{array}$ & $\begin{array}{c}0.00 \\
(0.92)\end{array}$ & $\begin{array}{c}0.00 \\
(0.51)\end{array}$ & $\begin{array}{c}0.00 \\
(0.47)\end{array}$ \\
\hline Captured Directors & $\begin{array}{c}0.00 \\
(0.93)\end{array}$ & $\begin{array}{c}0.00 \\
(0.86)\end{array}$ & $\begin{array}{c}0.00 \\
(0.81)\end{array}$ & $\begin{array}{l}-0.00 \\
(0.79)\end{array}$ \\
\hline CEO is Chair & $\begin{array}{c}0.00 \\
(0.96)\end{array}$ & $\begin{array}{l}-0.00 \\
(0.54)\end{array}$ & $\begin{array}{l}-0.01 \\
(0.28)\end{array}$ & $\begin{array}{c}0.02 \\
(0.27)\end{array}$ \\
\hline NYSE Listing & $\begin{array}{c}-0.00 \\
(0.56)\end{array}$ & $\begin{array}{l}-0.01 \\
(0.59)\end{array}$ & $\begin{array}{l}-0.02 \\
(0.10)\end{array}$ & $\begin{array}{c}0.01 \\
(0.68)\end{array}$ \\
\hline Log MVE & $\begin{array}{l}-0.01^{* *} \\
(0.01)\end{array}$ & $\begin{array}{l}-0.01 \\
(0.11)\end{array}$ & $\begin{array}{l}-0.00^{*} \\
(0.08)\end{array}$ & $\begin{array}{l}-0.01^{*} \\
(0.10)\end{array}$ \\
\hline Institutional Ownership & $\begin{array}{c}0.01 \\
(0.60)\end{array}$ & $\begin{array}{c}0.00 \\
(0.91)\end{array}$ & $\begin{array}{l}-0.00 \\
(0.96)\end{array}$ & $\begin{array}{c}0.02 \\
(0.48)\end{array}$ \\
\hline Cash-to-Assets & -0.04 & -0.05 & -0.03 & -0.01 \\
\hline
\end{tabular}



$(0.16)$
(0.17)
$(0.16)$

$(0.85)$

\begin{tabular}{lcccc} 
& $0.22^{* * *}$ & $0.25^{* * *}$ & 0.05 & $0.21^{* * *}$ \\
R\&D Intensity & $(0.00)$ & $(0.00)$ & $(0.44)$ & $(0.00)$ \\
Advertising Intensity & $0.12^{* *}$ & 0.06 & $0.08^{*}$ & 0.29 \\
& $(0.03)$ & $(0.39)$ & $(0.07)$ & $(0.16)$ \\
SG\&A Intensity & $-0.06^{* *}$ & $-0.09^{* *}$ & $-0.03^{* *}$ & -0.02 \\
& $(0.01)$ & $(0.04)$ & $(0.03)$ & $(0.58)$ \\
Short-Term Debt & 0.01 & 0.02 & -0.09 & 0.02 \\
& $(0.83)$ & $(0.72)$ & $(0.21)$ & $(0.81)$ \\
Operating Performance & $0.09^{* *}$ & $0.20^{*}$ & 0.03 & 0.02 \\
& $(0.05)$ & $(0.08)$ & $(0.21)$ & $(0.73)$ \\
Firm Risk & -0.05 & 0.24 & $-0.67^{* *}$ & -0.31 \\
SOX & $(0.80)$ & $(0.43)$ & $(0.05)$ & $(0.52)$ \\
& 0.00 & 0.01 & -0.00 & 0.01 \\
Business School & $(0.92)$ & $(0.60)$ & $(0.61)$ & $(0.29)$ \\
& $0.01^{* *}$ & $0.02^{* *}$ & 0.01 & \\
\hline Observations & $(0.03)$ & $(0.01)$ & $(0.11)$ & 75 \\
Pseudo R & 550 & 332 & 143 & 0.22 \\
\hline
\end{tabular}

The table presents the results of an OLS model regressing board, firm, and director characteristics on the cumulative abnormal announcement returns (CAARs) for the sample academic director appointments. CAARs are calculated employing a market model, estimated over the 255 days ending 46 days prior to the announcement date, using the CRSP equal-weighted index. The dependent variable is the two-day CAAR [-1,0], where the event date (day 0) is the earliest announcement of appointment to the board. The numbers in parentheses are $p$-values for two-sided tests. ${ }^{* * *}$, and ${ }^{* * *}$ denote statistical significance at the $10 \%, 5 \%$, and $1 \%$ levels, respectively. All models employ robust standard errors clustered at the firm level. Long Distance equals 1 if the distance is greater than the median value for all sample firms. SOX equals 1 if the director is appointed after 2002. All other variables are defined in the Appendix. 